DOE/RL-89-12

Revision 2 Draft A

UC-630

\title{
Hanford Site Ground Water Protection Management Plan
}

Date Published

October 1994



Approved for Public Release

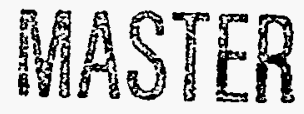

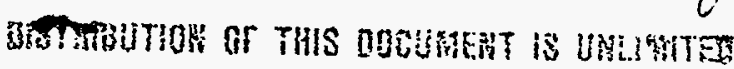




\section{DISCLAIMER}

This report was prepared as an account of work sponsored by an agency of the United States Government. Neither the United States Government nor any agency thereof, nor any of their employees, make any warranty, express or implied, or assumes any legal liability or responsibility for the accuracy, completeness, or usefulness of any information, apparatus, product, or process disclosed, or represents that its use would not infringe privately owned rights. Reference herein to any specific commercial product, process, or service by trade name, trademark, manufacturer, or otherwise does not necessarily constitute or imply its endorsement, recommendation, or favoring by the United States Government or any agency thereof. The views and opinions of authors expressed herein do not necessarily state or reflect those of the United States Government or any agency thereof. 


\section{DISCLAIMER}

Portions of this document may be illegible in electronic image products. Images are produced from the best available original document. 


\section{EXECƯTIVE SUMMARY}

Ground water protection at the Hanford Site consists of preventative and remedial measures that are implemented in compliance with a variety of environmental regulations at local, state, and federal levels. These measures seek to ensure that the resource can sustain a broad range of beneficial uses. To effectively coordinate and ensure compliance with applicable regulations, the U.S. Department of Energy has issued DOE Order 5400.1 (DOE 1988a) (now under revision). This order requires all U.S. Department of Energy facilities to prepare separate ground water protection program descriptions and plans. This document describes the Ground Water Protection Management Plan (GPMP) for the Hanford Site located in the state of Washington.

DOE Order 5400.1 specifies that the GPMP covers the following general topical areas: (1) documentation of the ground water regime; (2) design and implementation of a ground water monitoring program to support resource management and comply with applicable laws and regulations; (3) a management program for ground water protection and remediation; (4) a summary and identification of areas that may be contaminated with hazardous waste; (5) strategies for controlling hazardous waste sources; (6) a remedial action program; and (7) decontamination, decommissioning, and related remedial action requirements.

Many of the above elements are currently covered by existing programs at the Hanford Site; thus, one of the primary purposes of this document is to provide a framework for coordination of existing ground water protection activities. The GPMP provides the ground water protection policy and strategies for ground water protection/management at the Hanford Site, as well as an implementation plan to improve coordination of site ground water activities. This is a revision of the initial document prepared in 1989 (DOE/RL 1989). Subtier documents provide the detailed plans for implementing ground water-related activities and programs. Related schedule and budget information are provided in the 5-year plan for environmental restoration and waste management at the Hanford Site.

The basic ground water protection strategy for the Hanford Site involves near- and long-term actions. Near-term actions include vadose zone and ground water characterization and monitoring of waste source areas and contaminant plumes; the elimination of liquid effluent discharges to the soil column by June 1995, and to have treated effluent discharges appropriately permitted; implementation of a site-wide pollution prevention and waste minimization plan; and implementation of expedited response actions or accelerated remedial actions at priority waste sites. Long-term protection will be accomplished by removal, stabilization, and/or treatment of stored waste and waste released to the ground and ground water, as well as through ground water and vadose zone monitoring for the early detection of any leakage from treatment, storage and disposal facilities. Remediation of contaminant plumes will be performed in accordance with the Hanford Sitewide Groundwater Remediation Strategy (DOE/RL 1994a). These near- and long-term actions are mandated by the formal Hanford Federal Facility Agreement and Consent Order (Tri-Party Agreement) involving the Washington State Department of Ecology, the U.S. Department of Energy, and the U.S. Environmental Protection Agency (Ecology et al. 1989). 
DOE/RL-89-12, Rev. 2

Draft A

This page intentionally left blank 


\section{LIST OF TERMS}

AKART all known, available, and reasonable methods of prevention, control, and

ALARA treatment

BAT as low as reasonably achievable

CERCLA best available technology

\section{CFR}

Comprehensive Environmental Response, Compensation, and Liability Act of 1980

DOE Code of Federal Regulations

DOH

DST

Ecology

EPA

ERA

ERDF

ETF

FS

GeoDAT

GPMP

GWSP

$\mathrm{HAB}$

HEIS

HGIS

HPPS

IRM

LEMIS

LFI

U.S. Department of Energy

Washington State Department of Health

double-shell tank

Washington State Department of Ecology

U.S. Environmental Protection Agency

expedited response action

Environmental Restoration Disposal Facility

200 Areas Effluent Treatment Facility

feasibility study

NEPA

Geosciences Data Analysis Toolkit

Ground Water Protection Management Plan

Ground Water Surveillance Project

Hanford Advisory Board

Hanford Environmental Information System

Hanford Geographic Information System

Hanford Past Practices Strategy

interim remedial measure

NPDES

PNL

RA

Liquid Effluent Monitoring Information System

limited field investigation

National Environmental Policy Act of 1969

RCRA

$\mathrm{RCW}$

$\mathrm{RI}$

$\mathrm{RL}$

ROD

SALDS

SST

TEDF

Tri-Party

Agreement

National Pollutant Discharge Elimination System

TSD

USC

UST

Pacific Northwest Laboratory

WAC

remedial action

Resource Conservation and Recovery Act of 1976

Revised Code of Washington

remedial investigation

Richland Operations Office

Record of Decision

WHC

WPPSS

yr

State-Approved Land Disposal Site

single-shell tank

200 Areas Treated Effluent Disposal Facility

Hanford Federal Facility Agreement and Consent Order

treatment, storage, and/or disposal

United States Code

underground storage tank

Washington Administrative Code

Westinghouse Hanford Company

Washington Public Power Supply System

year 
DOE/RL-89-12, Rev. 2

Draft A

This page intentionally left blank. 
DOE/RL-89-12, Rev. 2

Draft A

CONTENTS

1.0 INTRODUCTION $\ldots \ldots \ldots \ldots \ldots \ldots \ldots \ldots \ldots \ldots \ldots \ldots \ldots \ldots \ldots \ldots$

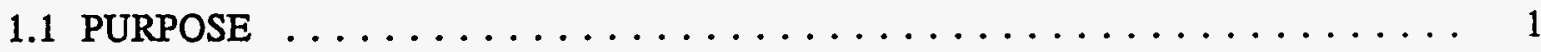

1.2 BACKGROUND $\ldots \ldots \ldots \ldots \ldots \ldots \ldots \ldots \ldots \ldots \ldots \ldots \ldots \ldots \ldots \ldots \ldots \ldots$

2.0 SITE HYDROGEOLOGY AND CONTAMINANT PLUMES $\ldots \ldots \ldots \ldots \ldots \ldots$

2.1 VADOSE ZONE $\ldots \ldots \ldots \ldots \ldots \ldots \ldots \ldots \ldots \ldots \ldots \ldots \ldots \ldots \ldots \ldots \ldots \ldots \ldots \ldots$

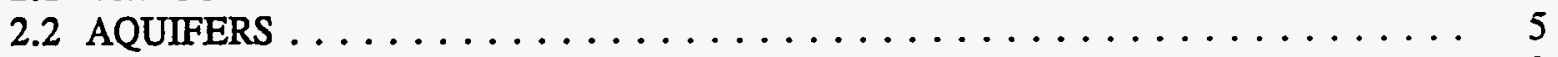

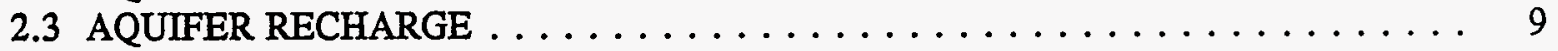

2.4 RIVER/GROUND WATER INTERACTION $\ldots \ldots \ldots \ldots \ldots \ldots \ldots \ldots \ldots$

2.5 CONTAMINANT PLUMES $\ldots \ldots \ldots \ldots \ldots \ldots \ldots \ldots \ldots \ldots \ldots \ldots \ldots$

2.6 GROUND WATER USE $\ldots \ldots \ldots \ldots \ldots \ldots \ldots \ldots \ldots \ldots \ldots \ldots$

3.0 GROUND WATER PROTECTION POLICY $\ldots \ldots \ldots \ldots \ldots \ldots \ldots \ldots \ldots$

3.1 PROPOSED FEDERAL STANDARDS $\ldots \ldots \ldots \ldots \ldots \ldots \ldots \ldots \ldots \ldots$

3.2 PROPOSED STATE STANDARDS $\ldots \ldots \ldots \ldots \ldots \ldots \ldots \ldots \ldots \ldots \ldots \ldots$

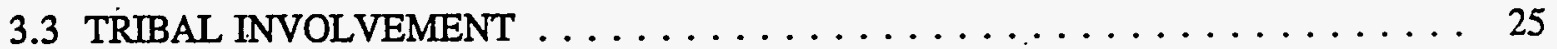

3.4 STAKEHOLDER INVOLVEMENT $\ldots \ldots \ldots \ldots \ldots \ldots \ldots \ldots \ldots \ldots$

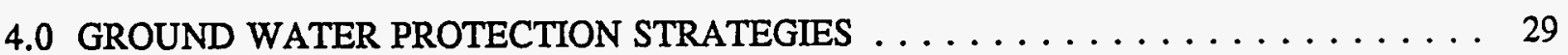

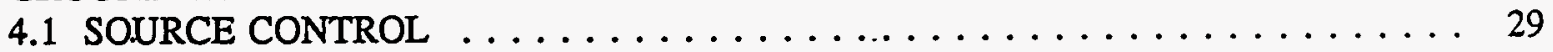

4.1.1 Pollution Prevention and Waste Minimization $\ldots \ldots \ldots \ldots \ldots \ldots 29$

4.1 .2 Waste Isolation $\ldots \ldots \ldots \ldots \ldots \ldots \ldots \ldots \ldots \ldots \ldots \ldots \ldots \ldots \ldots$

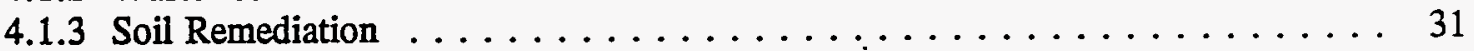

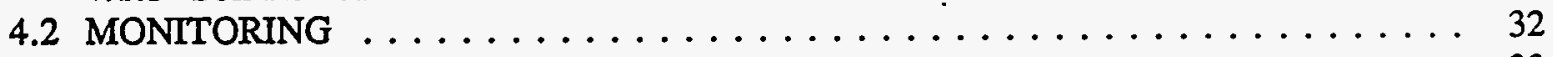

4.3 GROUND WATER REMEDIATION $\ldots \ldots \ldots \ldots \ldots \ldots \ldots \ldots \ldots \ldots \ldots$

5.0 GROUND WATER PROTECTION PROGRAMS $\ldots \ldots \ldots \ldots \ldots \ldots \ldots \ldots \ldots$

5.1 RCRA GROUND WATER ACTIVITIES $\ldots \ldots \ldots \ldots \ldots \ldots \ldots \ldots \ldots \ldots \ldots \ldots$

5.2 CERCLA GROUND WATER ACTIVITIES $\ldots \ldots \ldots \ldots \ldots \ldots \ldots \ldots \ldots . \ldots \ldots$

5.3 OPERATIONAL GROUND WATER ACTIVITIES $\ldots \ldots \ldots \ldots \ldots \ldots \ldots . \ldots \ldots$

5.4 SITEWIDE GROUND WATER SURVEILLANCE $\ldots \ldots \ldots \ldots \ldots \ldots \ldots \ldots$

5.5 VADOSE ZONE ACTIVITIES $\ldots \ldots \ldots \ldots \ldots \ldots \ldots \ldots \ldots \ldots \ldots \ldots \ldots \ldots$

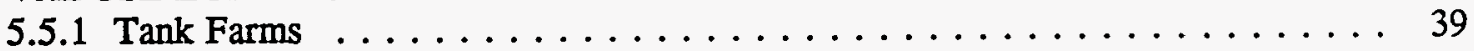

5.5 .2 Waste Management . . . . . . . . . . . . . . . . 40



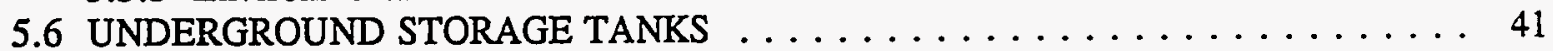

5.7 LIQUID EFFLUENT AND STATE WASTE DISCHARGE (216) PERMITS . . . . . 41

5.8 ONSITE PROJECT COORDINATION $\ldots \ldots \ldots \ldots \ldots \ldots \ldots \ldots \ldots \ldots .42$

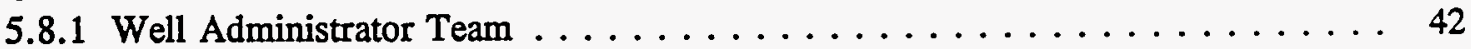

5.8.2 Hanford Environmental Information System $\ldots \ldots \ldots \ldots \ldots \ldots \ldots 43$

5.8.3 Auxiliary Data Tools . . . . . . . . . . . . . . . . . . 43





5.9.2 National Pollutant Discharge Elimination System $\ldots \ldots \ldots \ldots \ldots \ldots 44$ 
DOE/RL-89-12, Rev. 2

Draft A

CONTENTS (cont.)

6.0 GROUND WATER ISSUES $\ldots \ldots \ldots \ldots \ldots \ldots \ldots \ldots \ldots \ldots \ldots \ldots$

6.1 REGULATORY INTERFACE $\ldots \ldots \ldots \ldots \ldots \ldots \ldots \ldots \ldots \ldots \ldots \ldots \ldots$

6.2 PROGRAM INTERFACE $\ldots \ldots \ldots \ldots \ldots \ldots \ldots \ldots \ldots \ldots \ldots \ldots$

6.3 AUDIT FINDINGS AND STATUS $\ldots \ldots \ldots \ldots \ldots \ldots \ldots \ldots \ldots$





7.2 HANFORD GROUND WATER MANAGEMENT TEAM $\ldots \ldots \ldots \ldots \ldots \ldots$

7.2 .1 Hydrogeologic Coordination Group Chair . . . . . . . . . . . . . . 53

7.2.2 Hanford Ground Water Management Team Members . . . . . . . . . . . . . 53

7.3 GROUND WATER PROTECTION GROUP $\ldots \ldots \ldots \ldots \ldots \ldots \ldots \ldots \ldots$

7.4 HANFORD HYDROGEOLOGIC COORDINATION GROUP VISION $\ldots \ldots \ldots \ldots$

7.5 GOALS AND SCHEDULE $\ldots \ldots \ldots \ldots \ldots \ldots \ldots \ldots \ldots \ldots \ldots \ldots \ldots$



8.0 REFERENCES $\ldots \ldots \ldots \ldots \ldots \ldots \ldots \ldots \ldots \ldots \ldots \ldots \ldots \ldots \ldots \ldots$

\section{LIST OF FIGURES}

1. Relationship Between the Ground Water Protection Management Plan and Other Environmental Protection Programs and Plans Required by

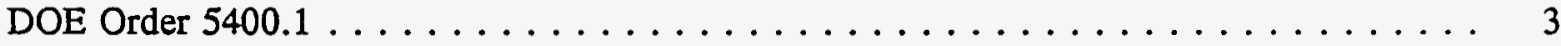

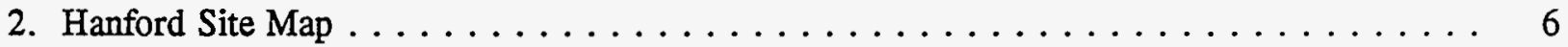

3. Generalized Geologic Cross Section of the Hanford Site . . . . . . . . . . . . . . . 7

4. Water Table Elevations for the Unconfined Aquifer at Hanford and in Parts of Franklin and Grant Counties, June $1993 \ldots \ldots \ldots \ldots$

5. Distribution of Hazardous Chemicals in Ground Water at Concentrations Above the Drinking Water Standard . . . . . . . . . . . . . . . . . . 13

6. Distribution of Radionuclides in Ground Water at Concentrations Above

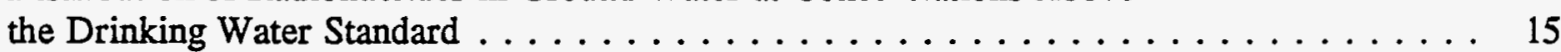



8. Hanford Hydrogeologic Coordination Group . . . . . . . . . . . . . . . . 52

9. Major Milestones Identified in the Tri-Party Agreement Action Plan . . . . . . . . . . . 56

\section{LIST OF TABLES}

1. Federal Laws and Applicable Regulations Associated With Ground Water Management . . . . . . . . . . . . . . . . . . . . . 21

2. Washington State Regulations Associated With Ground Water Management . . . . . . . . 23 


\subsection{INTRODUCTION}

This Ground Water Protection Management Plan (GPMP) for the Hanford Site fulfills the requirements of the U.S. Department of Energy (DOE) as set forth in DOE Order 5400.1, General Environmental Protection Program, Chapter III(4)(a) (DOE 1988a) (currently under revision). This document also fulfills the requirements of milestone M-13-81A of the Hanford Federal Facility Agreement and Consent Order (Tri-Party Agreement) signed by the Washington State Department of Ecology (Ecology), the U.S. Environmental Protection Agency (EPA) and the U.S. Department of Energy (DOE) (Ecology et al. 1989).

\subsection{PURPOSE}

A key purpose of the GPMP is to provide a framework for implementing the Hanford Site Strategic Plan (DOE/RL 1994b) goals and strategies for Site cleanup with regard to ground water. These include DOE's commitment to protecting the Site ground water from further degradation, protecting the Columbia River, providing a clean and healthy environment open to a variety of uses, and building positive working relationships with the tribes and other stakeholders so that their values and input are considered in the decision making process on ground water protection issues.

DOE Order 5400.1 stipulates the requirements of the GPMP in Section III-4-a. The requirements for the plan are:

- Documentation of the ground water regime with respect to quantity and quality

- Design and implementation of a ground water monitoring program to support resource management and comply with applicable laws and regulations

- A management program for ground water protection and remediation, including specific Safe Drinking Water Act of 1974, Resource Conservation and Recovery Act of 1976 (RCRA), and Comprehensive Environmental Response, Compensation, and Liability Act of 1980 (CERCLA) actions

- A summary and identification of areas that may be contaminated with hazardous substances

- A strategy for controlling sources of these contaminants

- A remedial action (RA) program that is part of the site CERCLA program

- Decontamination and decommissioning, and other remedial programs contained in DOE directives. 
DOE/RL-89-12, Rev. 2

Draft A

Tri-Party Agreement Milestone M-13-81A also provides specific requirements for this GPMP revision. The milestone states:

"Ecology, EPA and DOE agree that there is a need to coordinate measures required to manage and protect ground water resources at Hanford. A mechanism is needed that coordinates discharge to the ground, ground water withdrawal and treatment, and the treatment of liquid effluents that are discharged to the soil column. DOE Order 5400.1 requires such a ground water protection management program. Ecology, EPA and DOE agree that the document describing the Hanford Site Ground Water Protection Management (DOE/RL-89-12) will be revised to incorporate cleanup goals, TPA requirements and permitting concerning discharge to the ground, ground water withdrawal and the treatment of liquid effluents that are discharged to the soil column. The plan will be used to coordinate these efforts and to manage the Hanford Site ground water resource. It will be submitted in lieu of an operable unit work plan required by TPA Milestone M-13 in 1994. The plan will be reviewed on an annual basis to determine if amendments are necessary."

Most of the requirements of the GPMP are fulfilled by ongoing Hanford Site environmental programs and activities. The relationship of the GPMP to other environmental planning documents for the Hanford Site is shown in Figure 1. The main purpose of this revision of the GPMP is to summarize these programs/activities, present the existing framework of ground water protection management at the Hanford Site, and to establish a mechanism (implementation plan) for improved coordination of the ground water programs/activities. Specifically, this document discusses the site hydrogeology and contaminant plumes, ground water protection policy, ground water protection strategy (including cleanup goals), the various ground water protection programs (i.e., RCRA, CERCLA, Operational, and Ground Water Surveillance), ground water resources, ground water issues, and an implementation plan for improved coordination of these programs.

\subsection{BACKGROUND}

Work to characterize the hydrogeologic conditions and ground water quality has been conducted since the early days of Site operations. Jenkins (1922) performed a largely qualitative ground water study in the vicinity of the Hanford and White Bluffs townsites. Hydrogeologic characterization of the Hanford Site began with Piper (1944). Since that time, much work has been performed to characterize the upper aquifer, including Parker and Piper (1949); Bierschenk (1959); Newcomb et al. (1972); Kipp and Mudd (1973); Last et al. (1989); Lindsey (1991); Lindsey et al. (1991, 1992); Thorne et al. (1993); and Liikala (1994).

A brief summary of the ground water monitoring history is provided in Gerber (1992). Ground water monitoring began with operations in the mid-1940's when Site ground water was analyzed for radionuclides. In 1960, the volume of low-level liquid wastes discharged to the soil column in the 200 Areas was increasing. This, along with the rising 200 Areas ground water mounds and increasing activity levels in the ground water, prompted Site scientists to begin monitoring for the highly mobile ground water contaminants nitrate and tritium in 1961. At that time, additional monitoring wells were installed in many areas around the Site. Ground water quality monitoring has been conducted at the Hanford Site continuously since 1964 (e.g., Foster and Wilson 1965). 


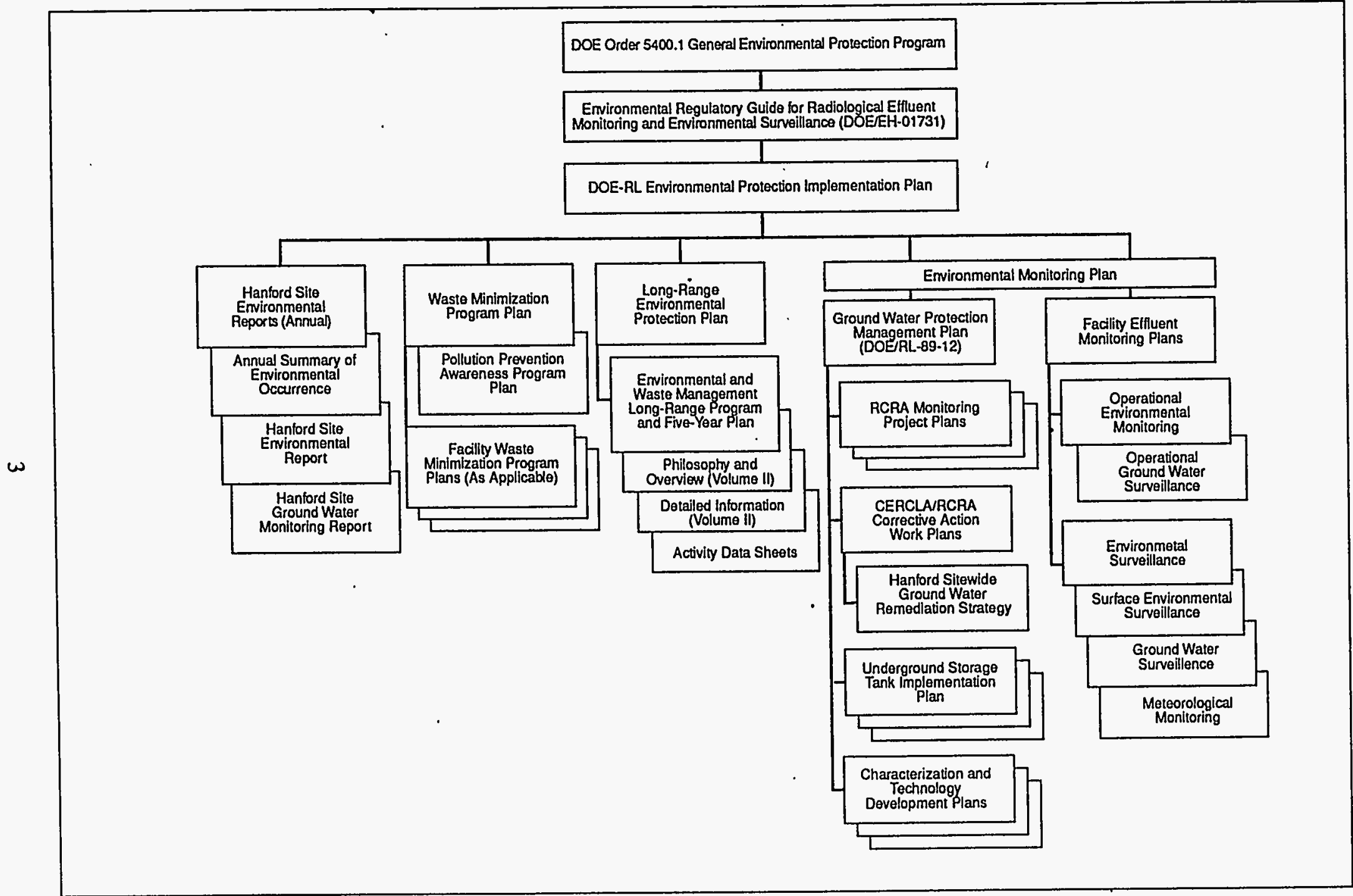




In the mid-1980's various environmental regulatory programs were implemented. Additional wells were installed and monitoring under the RCRA and CERCLA programs was initiated. Environmental research related to ground water protection and management were undertaken by the contractors at the Site, including ground water recharge studies, engineered barrier development, and further hydrogeologic characterization. Site recharge studies include those by Gee (1987); Routson and Johnson (1990); Rockhold et al. (1990); and Gee et al. (1992). The connection between the uppermost aquifer and the Columbia River is an important issue, since contaminated ground water from Hanford discharges to the river. Ground water and river interaction along the Hanford Reach of the Columbia River is described in Dirkes (1990); Peterson and Johnson (1992); and PNL (1994). Another important issue is aquifer intercommunication, whereby contaminants may move downward from a contaminated portion of the upper aquifer into deeper, uncontaminated basalt and interbed aquifers (see Section 2.2). Hydrogeologic information for the Site continues to be collected under various activities, such as from well installations, soil and ground water sampling performed under the Ground Water Surveillance Project (GWSP), RCRA, CERCLA, and Operational programs. A bibliography of ground water activities on the Hanford Site is provided in the GWSP annual report (e.g., Dresel et al. 1994).

With the closing of all of the Site production reactors, the primary Site focus has changed from that of defense production of plutonium to Site cleanup, science and technology, and economic diversification (DOE/RL 1994b). The major Site efforts now include waste management (tank farms, burial grounds, liquid effluents, etc.); environmental monitoring; and characterization, remediation, and decontamination and decommissioning, which are conducted in accordance with applicable federal and state environmental regulations and DOE orders. The Hanford Site Strategic Plan (DOE/RL 1994b) also more clearly acknowledges the significance of the Site's long-term role in providing science and technology and partnering in the economic diversification of the region around the Site. Ground water protection, management, and remediation on the Hanford Site presents a considerable challenge due to the large number of contaminated sites, wide extent of ground water contamination, and overlapping and potentially conflicting regulatory requirements. 


\subsection{SITE HYDROGEOLOGY AND CONTAMINANT PLUMES}

This section presents the geologic and hydrologic features that control the direction and rate of ground water flow. The major contaminant plumes and ground water use on the Hanford Site are also summarized.

The Hanford Site is located in the Pasco Basin, a broad sediment-filled depression that lies within the larger Columbia Plateau (Figure 2). The Pasco Basin sediments are composed mainly of the cataclysmic flood deposits of the Pleistocene (10,000 to 1.6 million years) Hanford formation and the underlying Pliocene (1.6 to 5.3 million years) Ringold Formation deposited by the ancestral Columbia River. These sediments overlie flood basalts of the Columbia River Basalt Group (Delaney et al. 1991). A generalized geologic cross section of the Hanford Site is shown in Figure 3. The Hanford Site is characterized by thick, poorly consolidated, sedimentary deposits, wide variability in ground water and contaminant movement, a deep extensive unconfined aquifer, and very limited onsite natural recharge to the unconfined aquifer and deeper confined aquifers within the basalts.

\subsection{VADOSE ZONE}

The soil column above the water table is dominated by unconsolidated glaciofluvial sandy gravels (informally designated as the Hanford formation) that were deposited during several episodes of cataclysmic flooding; the last major flood occurred about 13,000 years ago (Mullineaux et al. 1978). Although these typically coarse-grained sediments are highly transmissive to water, the downward movement of moisture in the vadose zone is retarded by heterogeneities in soil composition (e.g., silt or cemented layers). However, the combination of low annual precipitation and high evapotranspiration prevents most surface water from reaching the ground water. The thickness of the vadose zone ranges from $0 \mathrm{~m}(\mathrm{ft})$ near the Columbia River to over $91 \mathrm{~m}(300 \mathrm{ft})$ in the south-central portion of the Site (DOE 1988b).

The vadose zone stratigraphy in the Central Plateau (the general area around the 200 East and 200 West Areas; see Figure 2) influences the movement of liquid effluents through the soil column beneath many waste disposal sites. Layers of silt or cemented layers generally slow the downward movement of water, resulting in the lateral spreading of water and localized saturated zones (i.e., "perched" water zones) above the top of the unconfined aquifer. This condition may expand a contaminant source area beyond the physical dimensions of a disposal facility. It also may influence the time required for contaminants to reach the water table. Drainage may persist for extended periods following termination of wastewater disposal operations. The relationship between stratigraphy and disposal operations is an important element in planning ground water monitoring and remediation at the Hanford Site.

\subsection{AQUIFERS}

The unconfined aquifer generally occurs in unconsolidated or semi-consolidated silts, sands, and gravels of the Ringold Formation, which underlies the Hanford formation (see Figure 3). In the eastern and northern parts of the Site, the unconfined aquifer is within the Hanford formation. 
DOE/RL-89-12, Rev. 2

Draft A

Figure 2. Hanford Site Map.

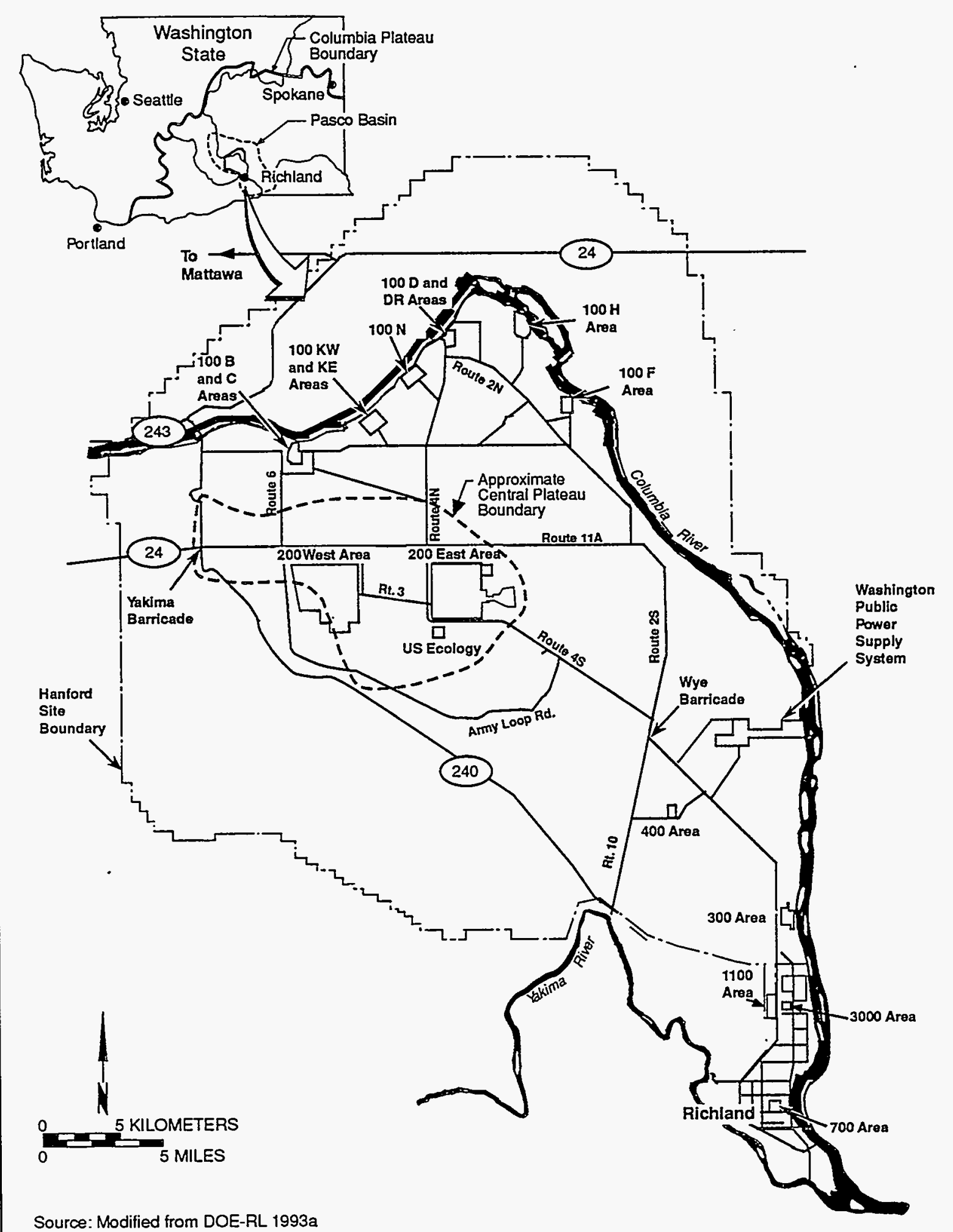

$943-1107 / 50156 / 10-21-94$ 


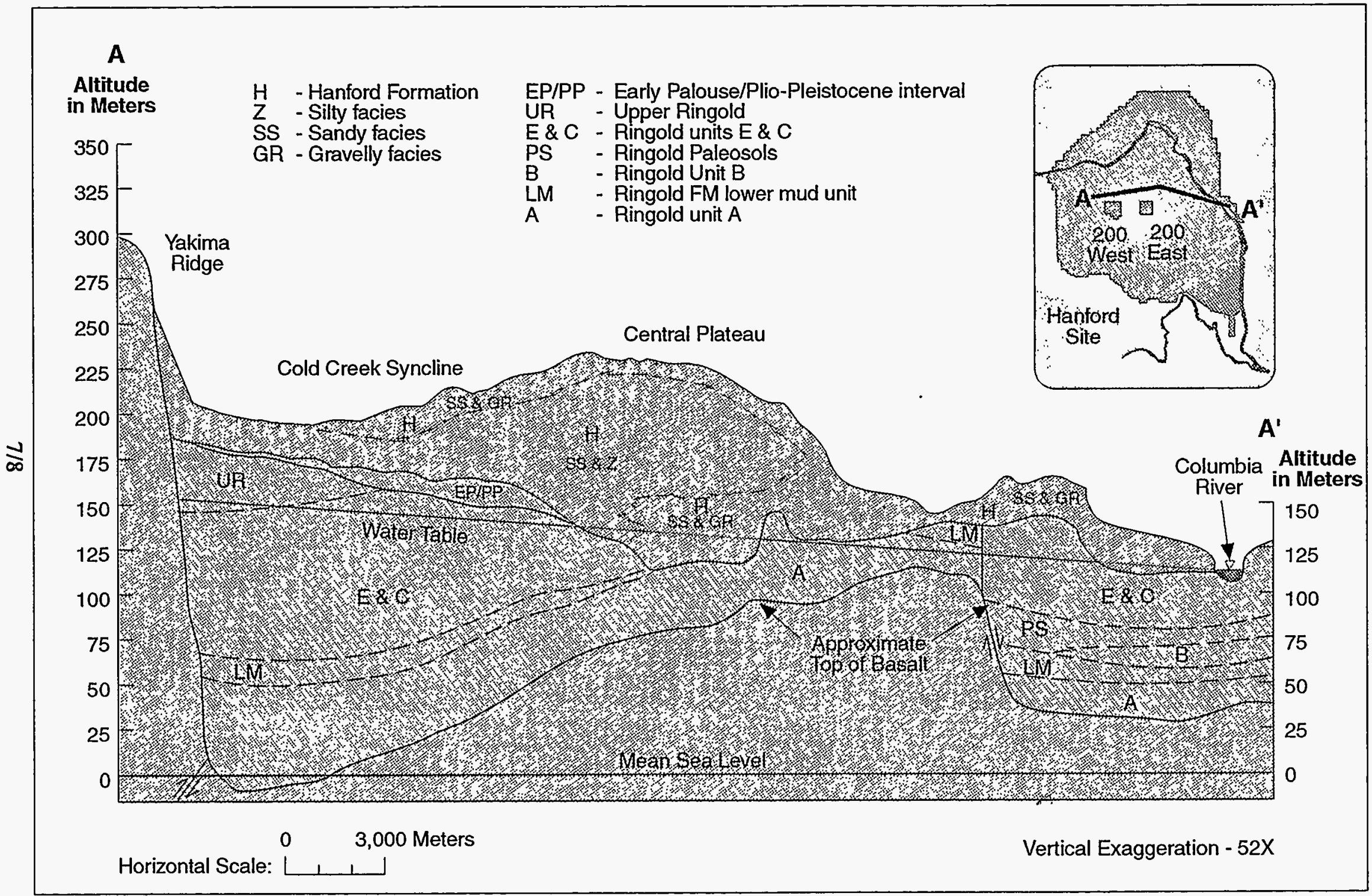


Ground water flow rates are highly variable due to aquifer heterogeneity, but generally range from less than $0.30 \mathrm{~m} /$ day $(1 \mathrm{ft} /$ day) to several meters/day ( $\mathrm{ft} /$ day) (Freshley and Graham 1988). The highest rates are in the unconsolidated gravelly sands of the Hanford formation, and in similar fluvial gravels of the Ringold Formation. The unconfined aquifer ranges in thickness from $0 \mathrm{~m}(\mathrm{ft})$ near the margins of the Pasco Basin to approximately $152 \mathrm{~m}$ (500 ft) near the center of the basin (Delaney et al. 1991). A water table contour map of the unconfined aquifer at Hanford and in adjacent areas north and east of the Site is shown in Figure 4. This figure shows that ground water flow in the 100 Areas of the Site is generally to the north and east toward the Columbia River. Ground water flow in the 200 Areas of the Site is generally from west to east toward the Columbia River, although some ground water flows north through the Gable Gap area (between Gable Butte and Gable Mountain; see Figure 4) and then toward the Columbia River. Figure 4 also shows that the water table is mounded beneath B Pond, located east of the 200 East Area.

Underlying the Ringold Formation are the Columbia River Basalts, which are extensive layers of flood basalt (lava). The basalts contain numerous confined aquifers, some of which are regional water sources. Vertical movement of water between aquifers may occur along fractures or faults in some areas (Early et al. 1988; Johnson et al. 1993), or where erosion of the uppermost basalt layers ${ }^{-}$ has created natural communication pathways between aquifers (Graham et al. 1984).

\subsection{AQUIFER RECHARGE}

Both natural and artificial sources of water recharge the aquifers within the Pasco Basin. The most significant volume source is irrigation water from the Columbia Basin Project outside of the area, although the influence on the Hanford Site is limited to the area which is north and east of the Columbia River (see Figure 2). Ground water in the unconfined and confined aquifers discharges to the river. Natural recharge at the Hanford Site from rain and snowmeit is variable, from over $100 \mathrm{~mm} / \mathrm{yr}$ ( $3.9 \mathrm{in} / \mathrm{yr}$ ) in bare sands and gravels, to near zero (i.e., nonmeasurable amounts) in siltloam soils, with or without plants (Gee et al. 1992).

A portion of the recharge to the unconfined aquifer beneath the Central Plateau comes from infiltration from natural and artificial sources in the upper Cold Creek and Dry Creek valleys (e.g., Black Rock Valley) to the west of the Hanford Site. Irrigation in these areas may also contribute to recharge, although the volume is uncertain because much of the irrigation water is lost to evapotranspiration. Artificial recharge caused by Hanford Site operations historically has produced major ground water mounds in the 200 East (e.g., B Pond; see Figure 4) and 200 West Areas (i.e., from U Pond). The reduction or cessation of liquid effluent disposal is resulting in decline of the water table across much of the 200 Areas. The appearance and disappearance of mounds and changes in the water table have altered the shape of contaminant plumes.

Near the southern boundary of the Hanford Site, ground water recharge to the unconfined aquifer results from ground water inflow from the Yakima River. Infiltration from irrigation west of the 1100 Area (e.g., Horn Rapids area; see Figure 2) likely contributes to this ground water inflow volume (Delaney et al. 1991). The city of Richland maintains infiltration ponds adjacent to the 1100 Area that create a ground water mound. The recharge from the Yakima River, irrigation, and the city of Richland ponds influences ground water flow directions in the southern portion of the Hanford Site. 
DOE/RL-89-12, Rev. 2

Draft A

Figure 4. Water Table Elevations for the Unconfined Aquifer at Hanford and in Parts of Franklin and Grant Counties, June 1993.

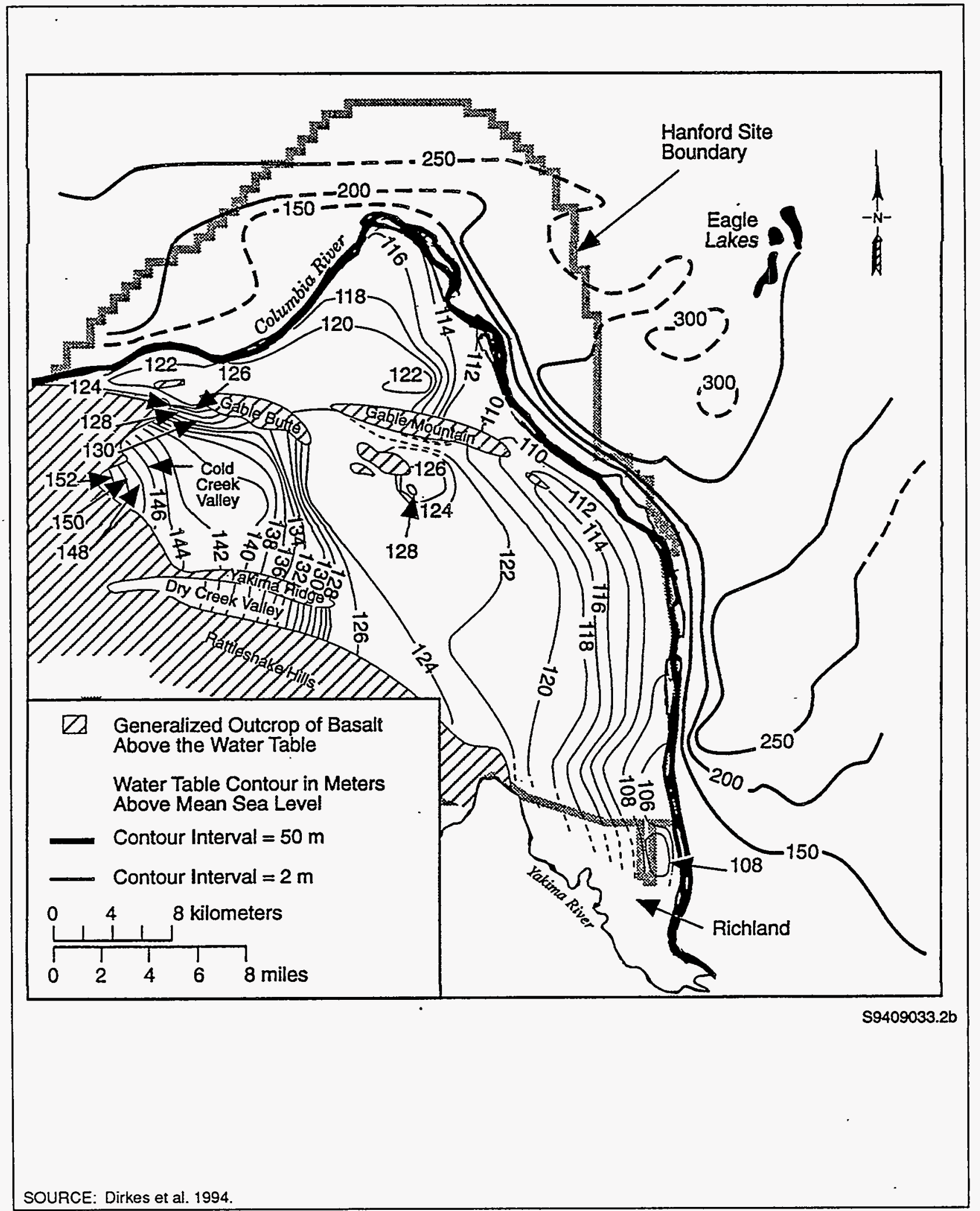


DOE/RL-89-12, Rev. 2

Draft A

\subsection{RIVER/GROUND WATER INTERACTION}

The interaction between the Hanford Site unconfined aquifer and the Columbia River is an important element in assessing contaminant impacts on the river system. Ground water and river interaction along the Hanford Reach of the Columbia River is described in Dirkes (1990); Peterson and Johnson (1992); and PNL (1994). River water moves into and out of the river bank during daily and seasonal stage fluctuations, causing variable water quality characteristics in shoreline monitoring wells and river bank seeps. The water quality of these wells and seeps can vary from that of river water, which drains back into the river after periods of high river stage, to nearly undiluted ground water, after extended periods of low river stage (Peterson and Johnson 1992). The overall (net) trend is that ground water in the unconfined aquifer eventually discharges to the Columbia River (see Figure 4).

\subsection{CONTAMINANT PLUMES}

The major contaminant plumes in the unconfined aquifer, as defined by exceedance of federal or state drinking water standards, are summarized in this section. For descriptive purposes, most of these plumes have been grouped into the Central Plateau and the 100 Areas adjacent to the Columbia River. Figures 5 and 6 show the general configuration of chemical and radioactive contaminant ground water plumes, respectively, on the Hanford Site (Dresel et al. 1994).

Central Plateau area ground water contaminant plumes include uranium, technetium-99, iodine-129, tritium, chlorinated hydrocarbons (i.e., carbon tetrachloride, chloroform, and trichloroethylene), and nitrate in and adjacent to the 200 West Area; and plutonium, cesium-137, strontium-90, technetium-99, iodine-129, and nitrate in and adjacent to the 200 East Area. Strontium-90 contaminant plumes are located adjacent to the reactors at five of the six 100 Area sites, tritium contaminant plumes are located at four of the 100 Area sites, and hexavalent chromium plumes are present at the 100-K, 100-D, 100-H, and 100-F Areas. A ground water contaminant plume containing uranium is also present in the 300 Area. Three ground water contaminant plumes (i.e., tritium, iodine-129, and nitrate) are more widely distributed at several areas on the Site as sitewide plumes.

Many of the ground water contaminant plumes overlap due to merging of the plume flow paths from different sources or because they were released simultaneously from the same source. The plumes are moving with the hydraulic gradient (i.e., in directions that are approximately perpendicular to the water table elevation contours shown on Figure 4). Based on current water table elevations and known aquifer properties, mobile contaminants in the 200 West Area are expected to take about 100 years to reach the Gable Gap area, followed by a much shorter travel time from Gable Gap to the Columbia River. Travel times from the 200 East Area to the Columbia River are expected to be on the order of 10 to 20 years because of the very high hydraulic conductivities downgradient of this area. In the 100 Areas, ground water flow toward the Columbia River averages $4.6 \mathrm{~m} /$ day (15 ft/day), although this rate is strongly influenced by river stage within several hundred meters (feet) of the shoreline (Friedrichs et al. 1977; Freshley and Graham 1988; DOE/RL 1994a).

Because of the geologic and hydrogeologic variations in the vadose zone and unconfined aquifer, as well as the different transport characteristics of the various contaminants, the contaminant plumes move through the vadose zone and aquifer at different rates. Based on borehole geophysical 
DOE/RL-89-12, Rev. 2

Draft A

This page intentionally left blank. 
Figure 5. Distribution of Hazardous Chemicals in Ground Water at Concentrations Above the Drinking Water Standard.

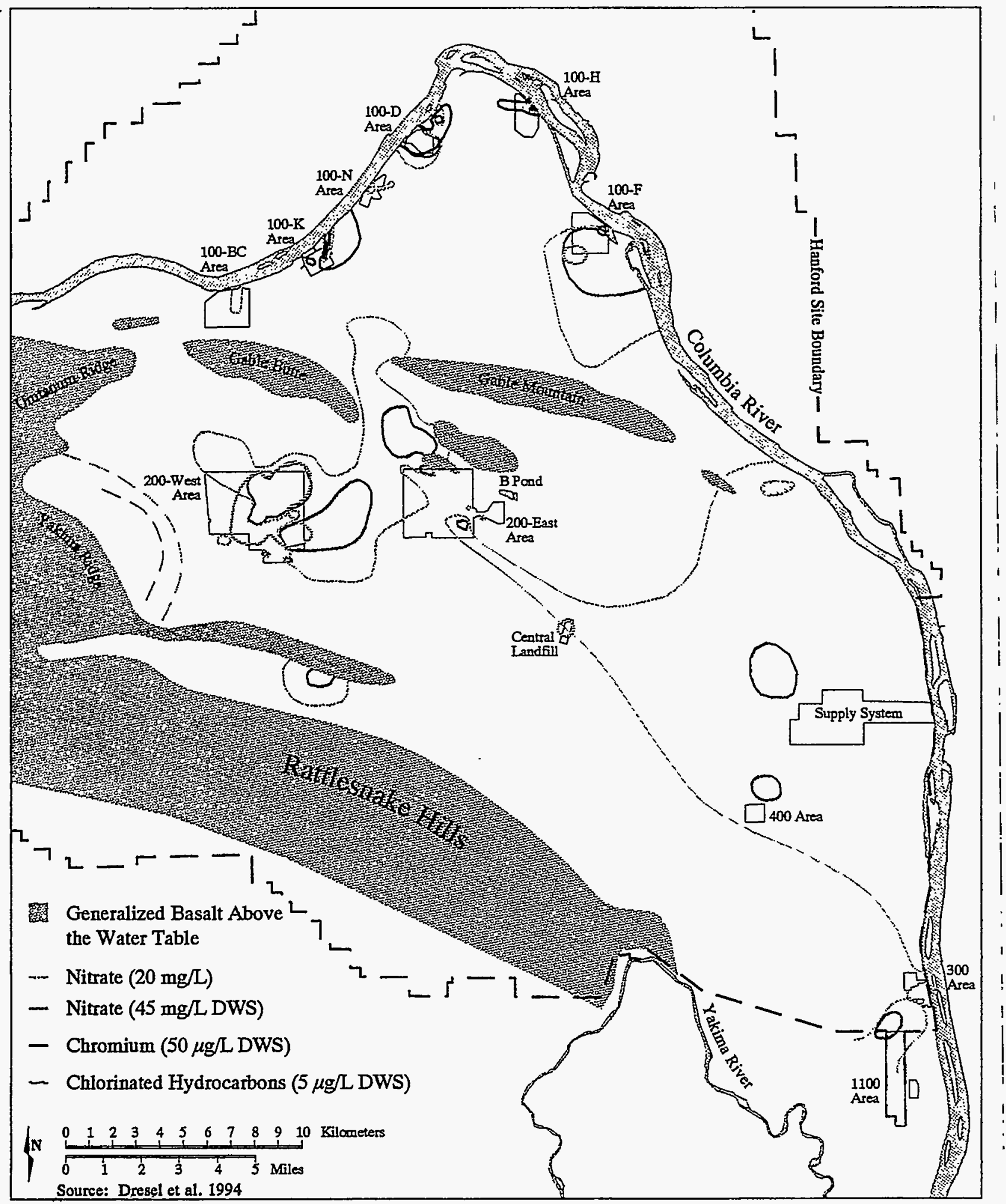


Figure 6. Distribution of Radionuclides in Ground Water at Concentrations Above the Drinking Water Standard.

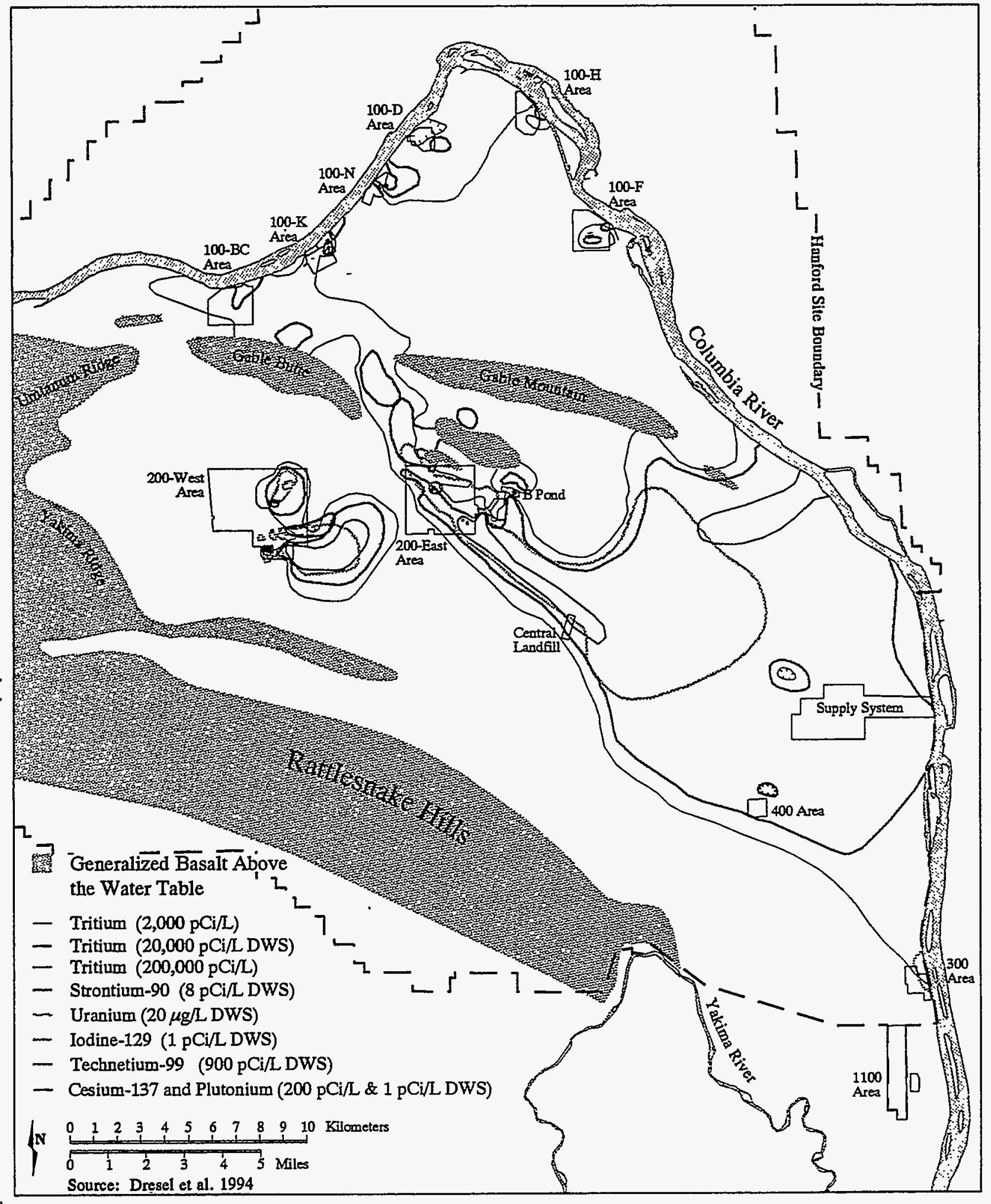


logging of vadose zone monitoring wells at the 200 Area tank farms (see Section 5.5.1), radioactive contaminants such as plutonium-239, cobalt- 60 , and cesium-137 that readily adsorb (i.e., adhere) to soil particles, are known to be mainly suspended in the vadose zone soils. These contaminants and others have formed "plumes" in the soil column which, if mobilized, could further contaminant ground water at the Site. Gamma-emitting radioactive contaminants can be defined and their movement monitored using high-resolution, spectral gamma-ray borehole logging equipment in vadose zone monitoring wells to provide an early assessment of potential ground water impacts. Carbon tetrachloride and trichloroethylene may be present in the subsurface as non-aqueous phase liquids. These compounds can introduce difficulties in characterizing their extent and in implementing appropriate remedies for their removal, because they differ in physical properties and transport characteristics from contaminants which are dissolved in ground water.

\subsection{GROUND WATER USE}

Due to the nature of the Site's previous defense mission involving the disposal of large quantities of wastewater to the ground, coupled with the availability of surface water from the Columbia River, the ground water resource at the Hanford Site has been used sparingly. Adjacent to the Hanford Site, ground water and, to a larger extent, surface water are used primarily for irrigation and domestic water supply. Current uses of Hanford Site ground water is described in this section. Goals for future ground water use at the Site are described in Section 4.3.

Nine drinking water sources at the Hanford. Site are (or can be) obtained from ground water (two in the 400 Area [one primary, one backup]; two at the Washington Public Power Supply System [WPPSS] nuclear power plant [backup to surface water source]; and one each at the Hanford Patrol Firing Range, Yakima Barricade, 300 Area, Rattlesnake Mountain observatory, and Fitzner/Eberhardt Arid Lands Ecology Reserve headquarters). Three Site wells are used for emergency backup water supply. Two of the wells are used at B Plant in the 200 East Area for emergency process tank cooling water. These wells are tested every two weeks for 4 hours at full capacity. The third well is used for emergency cooling water for the AY and AZ Tank Farm ventilation systems and is only utilized on an emergency basis.

The seven drinking water sources at the Hanford Site (excluding the WPPSS wells) which are (or can be) obtained from ground water are monitored for contaminants per Washington Administrative Code (WAC) $173-200$ and WAC 246-290 by the Hanford Environmental Health Foundation and the results are submitted to the Washington State Department of Health (DOH). These wells are typically sampled on a quarterly basis and analyzed for radionuclides (alpha, beta, tritium, strontium-90, and gamma), although the 400 Area wells are also sampled monthly for tritium and annually for iodine-129 (Bisping 1994). Tritium from the sitewide tritium plume has been detected in the 400 Area water supply, but average tritium concentrations in this source have been below state and federal drinking water standards.

There are five ground water wells located at the WPPSS plant site. Two of these wells were formerly used for construction water supply and fire protection, but are not actively used at this time. Two wells are shallow unconfined aquifer wells that are used for backup potable water supply as discussed above and the other is a confined aquifer monitoring well. These three wells are all sampled by WPPSS personnel on a quarterly basis and analyzed for radionuclides, and less frequently, for nitrates and volatile organic compounds. 
DOE/RL-89-12, Rev. 2

Draft A

This page intentionally left blank 
DOE/RL-89-12, Rev. 2

Draft A

\subsection{GROUND WATER PROTECTION POLICY}

DOE Order 5400.1 provides the basis for the ground water protection policy at all DOE facilities, including the Hanford Site. Pursuant to this order, it is DOE policy to:

- Conduct its operations in an environmentally safe and sound manner

- Protect the environment and the public

- Have all DOE activities reflect protection of the environment and the public by ensuring incorporation of national environmental protection goals in the implementation of DOE programs

- Advance the goals of restoring and enhancing environmental quality, and ensuring public health

- Conduct DOE operations in compliance with the letter and spirit of applicable environmental statutes, regulations, and standards

- Provide good environmental management of all its programs and at all its facilities to correct existing environmental problems, minimize risks to the environment or public health, and anticipate and address potential environmental problems before they pose a threat to the quality of the environment or the public welfare (DOE 1988a).

It is recognized that the prevention of ground water contamination is eminently preferable to ground water remediation, based on risks to the environment and human health, as well as cost-effectiveness. Therefore, it is DOE policy to review and practice source control and appropriate monitoring to ensure that contaminant releases and discharges are as low as reasonably achievable (ALARA) and below regulatory limits.

Disposal of liquid wastes directly to the soil column from production processes was an accepted practice throughout much of the history of Site operation. This disposal practice, plus liquid waste tank leaks and spills, has created numerous ground water and vadose-zone contaminant plumes in the operation areas. These contaminant plumes have been, and will continue to be evaluated, ranked according to magnitude and extent of contamination, and prioritized for remedial efforts in accordance with the Hanford Sitewide Groundwater Remediation Strategy (DOE/RL 1994a). This strategy document is an integral part of the GPMP for the Hanford Site.

Ecology is the lead regulatory agency for state-led regulatory programs at Hanford and EPA is the lead regulatory agency for federal-led programs at the Site. These agencies have the responsibility to ensure that the Hanford Site complies with federal and state environmental laws.

Successful implementation of the Hanford Site ground water protection policy through the various ground water programs and activities necessitates tribal, stakeholder (e.g., the public, local government, interested groups) and regulatory acceptance of both the process and the outcome. That acceptance is more likely to occur when informed groups are provided meaningful opportunities to participate in the process and help determine the outcome. This GPMP was developed with recognition that stakeholder and tribal values should shape program objectives and aid in prioritizing 
the sequence of program actions. While there is a great diversity of viewpoints among the tribes and stakeholders in cleanup of the Hanford Site, there are common values that may serve as themes for building consensus and providing direction to the ground water programs.

It is necessary to have a vision for the cleanup of the Hanford Site. This vision is embodied within the Hanford Site Strategic Plan (DOE/RL 1994b). The desired future uses for the land and resources of the Hanford Site provide the basis for determining the goals of ground water protection and remediation.

Some of the more important federal and state ground water regulations, as well as DOE orders that form the basis of the Hanford Site ground water protection policy and programs, are summarized in Tables 1 and 2. Proposed federal and state standards which may impact the current policy and ground water programs, are briefly described in the following sections. It is DOE's policy to include the tribes, all interested groups and the public at large (stakeholders) in the decision making process regarding ground water protection and other policy issues at Hanford. For this reason, sections on tribal and stakeholder involvement (and their ground water protection values) are also included in this chapter.

\subsection{PROPOSED FEDERAL STANDARDS}

Proposed rule 10 Code of Federal Regulations (CFR) 834 would essentially codify the DOE requirements set forth in DOE. Order 5400.5 and parts of DOE Order 5400.1. This proposed rule would require the cessation of the disposal of liquid radiological waste to the soil column "as soon as practicable," and prohibit new or increased discharges to active or virgin soil columns. Former radioactive effluent receiving units (cribs, trenches, etc.) would need to be managed or decontaminated in such a manner as to comply with ALARA requirements, and would not be allowed to receive any liquid effluent. (including uncontaminated effluent). Ground water contamination levels would have to conform to ALARA requirements, and the ground water would have to be protected from radiological and nonradiological contamination in accordance with the ground water protection management plan applicable to the activity. Although there is no known practicable method for removing tritium from liquid effluent streams, facilities and operations are to be designed and operated so that tritium sources and releases are considered in the ALARA process (DOE 1990a).

The EPA has published in the Federal Register a notice of proposed rulemaking for development of Radiation Site Cleanup Standards (proposed as 40 CFR 196). The working draft of the proposed regulations presents a cleanup standard of 15 millirems per year annual effective dose in excess of natural background radiation levels. The working draft also contains environmental protection standards for ground waters that are current or potential future sources of drinking water. The standards are based on the limits established under the federal drinking water regulations (40 CFR 141). However, if cleanup to these levels is not technically achievable, the proposed standard allows the use of institutional controls to ensure that the public will not be exposed to ground water contaminated above alternative concentration limits, maximum concentration limits, or maximum contaminant level goals in 40 CFR 141. 
Table 1. Federal Laws and Applicable Regulations Associated With Ground Water Management. (2 sheets)

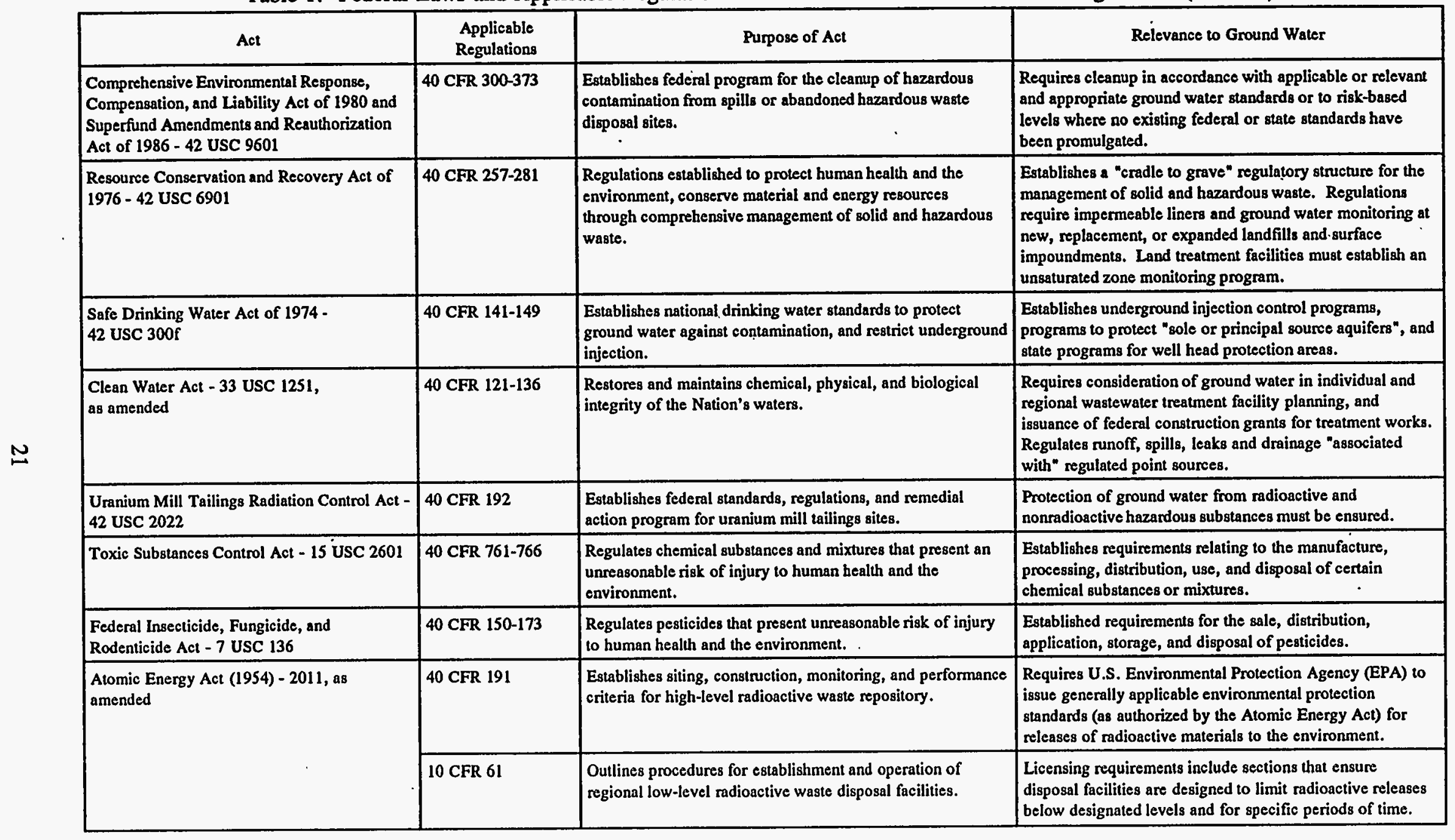


'spos sasvis pมाиน $=$ วSก



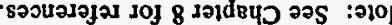

\begin{tabular}{|c|c|c|c|c|}
\hline \multirow{4}{*}{ 这 } & 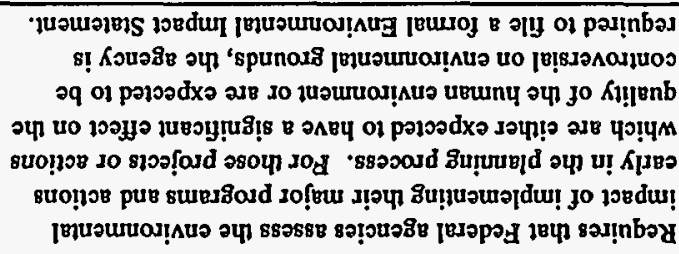 & 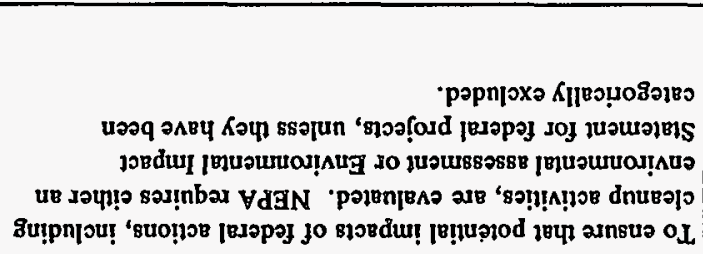 & 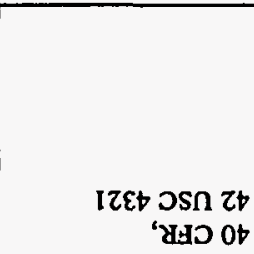 & 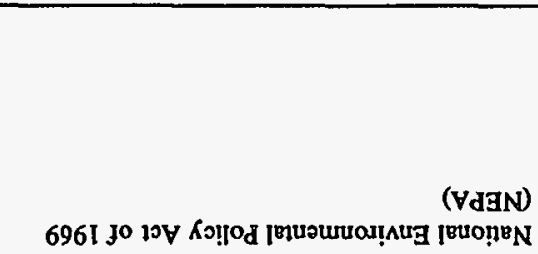 \\
\hline &  &  & 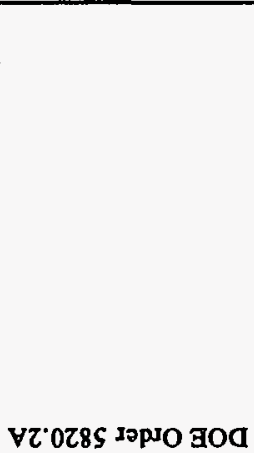 & \\
\hline & 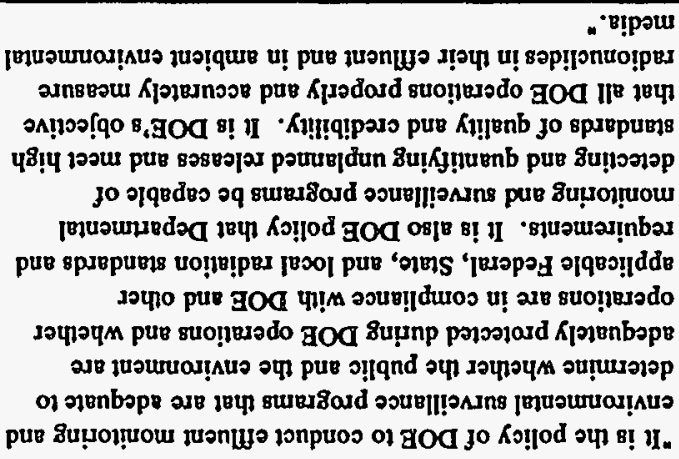 & 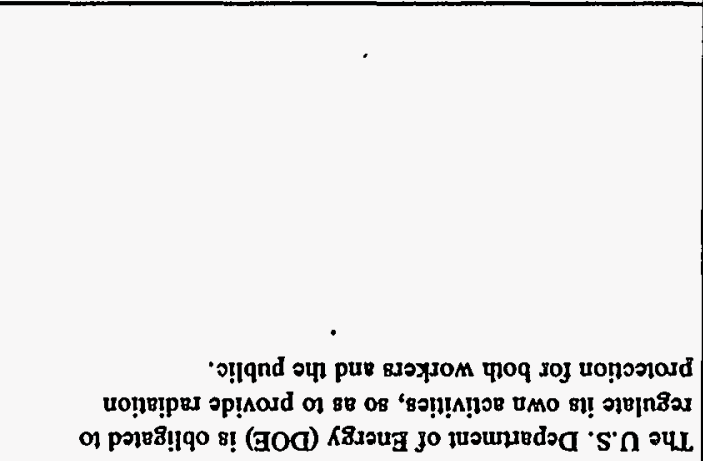 & $\begin{array}{r}\text { Sroots pur } \\
\text { ro0ts sropio 3Od }\end{array}$ & 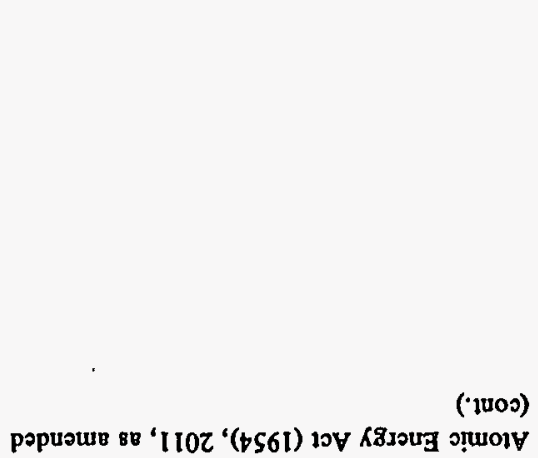 \\
\hline & 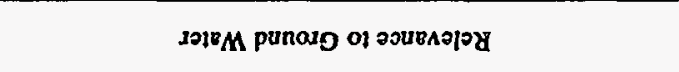 & 20V jo 280dund & 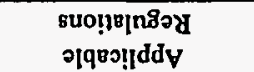 & IOV \\
\hline
\end{tabular}

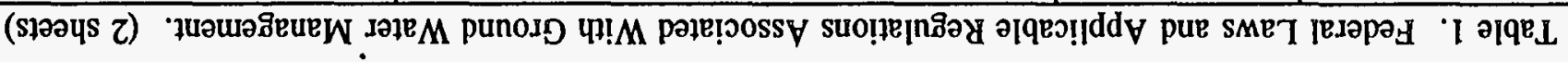


Table 2. Washington State Regulations Associated With Ground Water Management. (2 sheets)

\begin{tabular}{|c|c|c|}
\hline Regulation & Purpose & Applicability to Ground Water Management \\
\hline $\begin{array}{l}\text { Water Quality Standards for Ground Waters of } \\
\text { the State of Washington (WAC 173-200) }\end{array}$ & $\begin{array}{l}\text { Establishes minimum quality standards and antidegradation policy for } \\
\text { ground water. }\end{array}$ & $\begin{array}{l}\text { Imposes ground water quality criteria for primary and secondary } \\
\text { contaminants and some radiomuclides. }\end{array}$ \\
\hline $\begin{array}{l}\text { Water Quality Standards for Surface Waters of } \\
\text { the State of Washington (WAC 173-201a) }\end{array}$ & $\begin{array}{l}\text { Establishes water quality standards and classes for surface waters of } \\
\text { Washington State. }\end{array}$ & $\begin{array}{l}\text { Surface water and ground water are often in direct communication. } \\
\text { For example, Hanford Site ground water discharges to the Columbia } \\
\text { River. }\end{array}$ \\
\hline $\begin{array}{l}\text { Underground Storage Tank Regulations } \\
\text { (WAC 173-360) }\end{array}$ & $\begin{array}{l}\text { Regulates installation, monitoring, and mitigation of deficiencies in } \\
\text { underground storage tanks. Radioactive and mixed waste are exempt. }\end{array}$ & $\begin{array}{l}\text { Requires owners/operators of underground storage tanks to monitor } \\
\text { ground water quality. }\end{array}$ \\
\hline Dangerous Waste Regulations (WAC 173-303) & $\begin{array}{l}\text { Implements rules for designating, monitoring, and managing } \\
\text { dangerous waste. }\end{array}$ & $\begin{array}{l}\text { Requires owners/operators of facilities to conduct vadose zone and } \\
\text { ground water quality monitoring and prepare a response program. }\end{array}$ \\
\hline $\begin{array}{l}\text { Minimum Functional Standands for Solid Waste } \\
\text { Handling (WAC 173-304) }\end{array}$ & $\begin{array}{l}\text { Establishes minimum standards for disposal of solid waste; does not } \\
\text { include dangerous or radioactive waste. }\end{array}$ & $\begin{array}{l}\text { Imposes design standards and vadose zone and ground water } \\
\text { monitoring requirements to protect ground water from leachate. }\end{array}$ \\
\hline $\begin{array}{l}\text { State Waste Discharge Permit Program } \\
\text { (WAC 173-216) }\end{array}$ & $\begin{array}{l}\text { Implements permit program applying to discharge of waste to surface } \\
\text { waters and ground waters. }\end{array}$ & Controls discharge of waste to ground water. \\
\hline $\begin{array}{l}\text { Model Toxics Control Act Cleanup Regulations } \\
\text { (WAC 173-340) }\end{array}$ & $\begin{array}{l}\text { Governs the characterization and cleanup of hazardous substance } \\
\text { releases. }\end{array}$ & $\begin{array}{l}\text { Requires ground water system characterization and ground water } \\
\text { quality assessment at regulated sites. }\end{array}$ \\
\hline $\begin{array}{l}\text { Submission of Plans and Reports for Construction } \\
\text { of Wastewater Facilities (WAC 173-240) }\end{array}$ & $\begin{array}{l}\text { Requires submission of plans and reports for construction or } \\
\text { modification of wastewater facilities. }\end{array}$ & Requires "geohydrologic" evaluation in engineering report. \\
\hline $\begin{array}{l}\text { Ground Water Management Areas and Programs } \\
\text { (WAC 173-100) }\end{array}$ & $\begin{array}{l}\text { Allows the Washington State Department of Ecology to designate } \\
\text { areas with peculiar need for ground water management and also } \\
\text { provides as a funding mechanism. }\end{array}$ & $\begin{array}{l}\text { Forges cooperative management programs for ground water between } \\
\text { local, state, tribal, and federal interests. }\end{array}$ \\
\hline $\begin{array}{l}\text { Minimum Standards for Construction and } \\
\text { Maintenance of Wells (WAC 173-160) }\end{array}$ & Sets standards for drilling and water well construction. & $\begin{array}{l}\text { Protects ground water quality from impairment by intermingling of } \\
\text { ground waters or wellhead surface contamination. }\end{array}$ \\
\hline $\begin{array}{l}\text { Underground Injection Control Plan } \\
\text { (WAC 173-218) }\end{array}$ & $\begin{array}{l}\text { Establishes procedures/practices for implementation of the federal } \\
\text { Safe Drinking Water Act of } 1974 \text {. }\end{array}$ & $\begin{array}{l}\text { Controls the discharge of waste or harmful fluids to ground water } \\
\text { through wells. }\end{array}$ \\
\hline $\begin{array}{l}\text { Protection of Withdrawal Facilities Associated } \\
\text { with Ground Water Rights (WAC 173-150) }\end{array}$ & $\begin{array}{l}\text { Protects availability and quality of ground water to holders of ground } \\
\text { water rights. }\end{array}$ & $\begin{array}{l}\text { Protects holders of ground water rights from loss of use due to } \\
\text { contamination or depletion. }\end{array}$ \\
\hline $\begin{array}{l}\text { Protection of Upper Aquifer Zones } \\
\text { (WAC 173-154) }\end{array}$ & Protection of ground water within the upper aquifers. & $\begin{array}{l}\text { Protects near-surface ground water from depletion or quality } \\
\text { impairment. }\end{array}$ \\
\hline $\begin{array}{l}\text { Minimum Guidelines to Classify Agriculture, } \\
\text { Forest, Mineral Lands and Critical Areas } \\
\text { (WAC 365-190) }\end{array}$ & $\begin{array}{l}\text { Directs local governments to classify lands as part of the Growth } \\
\text { Management Act (Department of Community Development 1990) }\end{array}$ & Requires cities and counties to classify aquifer recharge areas. \\
\hline
\end{tabular}


Table 2. Washington State Regulations Associated With Ground Water Management. (2 sheets)

\begin{tabular}{|l|l|l|}
\hline \multicolumn{1}{|c|}{ Regulation } & \multicolumn{1}{|c|}{ Purpose } & \multicolumn{1}{|c|}{ Applicability to Ground Water Management } \\
\hline On-Site Sewage Disposal (WAC 246-272) & Regulates onsite septic systems. & $\begin{array}{l}\text { Establishes zones of separation between drainfields and ground } \\
\text { water. }\end{array}$ \\
\hline Public Water Supplies (WAC 246-290) & $\begin{array}{l}\text { Protect the health of consumers using public drinking water supplies } \\
\text { and provides protection of wellhead and catchment areas contributing } \\
\text { to water supply wells. }\end{array}$ & $\begin{array}{l}\text { Ensures adequate design, construction, sampling, management, } \\
\text { maintenance, and operation practices for public water supplies and } \\
\text { provide high quality drinking water in a reliable manner and in a } \\
\text { quantity suitable for intended use. }\end{array}$ \\
\hline
\end{tabular}

Note: See Chapter 8 for references.

WAC $=$ Washington Administrative Code. 
EPA is currently preparing a draft document that will define vadose zone monitoring, the methods and types of equipment to be used, and when and how the methods and equipment should be used to best advantage. EPA may then develop rule making to require adherence to specific vadose zone monitoring methods, which would be directly applicable at the Hanford Site with its thick vadose zone.

\subsection{PROPOSED STATE STANDARDS}

Rules addressing hydraulic continuity between surface water and ground water are undergoing formulation and review under the direction of Ecology's Water Resources Program. Although hydraulic continuity regulations will focus on the degree of exchange of quantities of surface water and ground water, quality impairment will also be addressed as provided in the empowering laws including the Water Resources Act of 1971 (Revised Code of Washington [RCW] 90.54) and the Regulation of Public Ground Water (RCW 90.44).

Primarily as a result of the Growth Management Act (RCW 36.70A), Washington State has recently implemented rules directly or peripherally affecting statewide ground water management. The Washington State Department of Community Development administers WAC 365-190, "Minimum Guidelines to Classify Agriculture, Forest, Mineral Lands, and Critical Areas." These guidelines contain provisions for protection of "aquifer recharge areas" (under a general heading of "Critical Areas").

\subsection{TRIBAL INVOLVEMENT}

The Hanford Site is located on land ceded by the Confederated Tribes of the Umatilla Indian Reservation and the Confederated Tribes and Bands of the Yakama Indian Nation to the United States in the Treaties of 1855 . The Nez Perce Tribe, by virtue of another treaty, also retains fishing rights on the Columbia River. Archeological records indicate that use and occupation of parts of the Site by tribal ancestors may extend as far back as 11,000 years ago. There are over 150 recorded archeological sites within Hanford's boundaries. Because the general public has had limited access to Hanford over the past 50 years, these cultural resources are still intact at the site. These cultural resources are especially valuable because many others have been lost to hydroelectric development, farming, and industrial and residential expansion in the area. The Columbia River also holds much importance to the tribes.

It is the intention of DOE to protect the onsite cultural resources of the tribes, respect tribal treaty rights, and to consult the tribes in decisions made regarding ground water protection and restoration. Because of the increasing number of issues with the potential to affect tribal interests, the Richland Operations Office (RL) established the Indian Nations Program. Tribal participation in Hanford's Five-Year Restoration and Waste Management Plan is an important part of this program. The tribes are interested in environmental protection and restoration, due to possible future land ownership and land use rights, and the impact of contaminated ground water on the Columbia River. The tribes have been involved in the Hanford Future Site Uses Working Group (Working Group), the Hanford Tank Waste Task-Force, the Hanford Environmental Dose Reconstruction Project, the Hanford Advisory Board ( $\mathrm{HAB}$ ) and continue to be involved in meetings and consultations regarding 
DंOE/RL-89-12, Rev. 2

Draft A

Site issues. They recently provided input which was used in developing the Hanford Sitewide Groundwater Remediation Strategy (DOE/RL 1994a). Ground water protection values expressed by the tribes include the following:

- Protect the environment and ground water against contamination

- Protect human health and worker safety

- Protect the Columbia River

- Proceed with ground water remediation

- Develop new technologies to clean up contaminants that may not be remediated with current technologies.

The Confederated Tribes of the Umatilla Indian Reservation hosted the Hanford Ground Water Summit in July 1994. The purpose of the meeting was to provide tribal representatives with a detailed overview of DOE's current ground water remediation and ground water protection activities at Hanford and to open and establish lines of communication and opportunities for future interaction with DOE, its contractors, and the regulatory agencies.

\subsection{STAKEHOLDER INVOLVEMENT}

It is DOE policy to include the public in decisions made regarding ground water protection and restoration at Hanford. Various forums have been provided so that DOE can work with these groups in deciding on protective and remedial activities. Past public participation activities have included the Working Group (Drummond 1992) and the Hanford Tank Waste Task Force (Hanford Tank Waste Task Force 1993). Additionally, a public comment period follows the issuance of certain primary environmental documents, as listed in Section 10.6 of the Tri-Party Agreement. The comments that are received are considered before the publication of the final document.

The Working Group efforts were based on the belief that the Hanford cleanup would be well served by having a better understanding of the range of possible future uses for the site after cleanup was completed. The Working Group identified a range of possible future uses for each of six major geographic areas of the Hanford Site. The Working Group recommended the following restrictions on the use of ground water:

- No use of the contaminated ground water should occur if it would jeopardize public health and safety

- No use of surface or ground water, whether contaminated or not, should occur if this usage would adversely change hydrologic conditions so as to increase the spread of contaminated plumes, or increase the speed of contaminated ground water flow to the Columbia River. 
The Working Group identified areas where ground water should be returned to "unrestricted" status and areas where ground water use would be "restricted" for the foreseeable future. The Working Group recommended implementation of a combination of strategies to deal with contaminated ground water:

- Removing the source of the potential contaminants prior to their reaching ground water

- Reducing and eliminating as soon as possible discharges into the soil to minimize further ground water contamination and to slow the speed of contaminant movement toward the Columbia River

- Treating the contaminated ground water itself.

The Working Group recognized that application of each strategy would vary due to the nature of the contaminant, technical feasibility, and threat to human or ecological health.

The Hanford Tank Waste Task Force was convened in May 1993 by DOE, EPA, and Ecology. These three parties renegotiated key aspects of the Tri-Party Agreement. The Hanford Tank Waste Task Force mission was to develop values from a broad cross section of stakeholders relative to the Tank Waste Remediation System and the overall Tri-Party Agreement package. The Tank Waste Task Force consisted of representatives from local and county governments, state of Oregon, Confederated Tribes of the Umatilla Indian Reservation, Confederated Tribes and Bands of the Yakama Indian Nation, Nez Perce Tribe, public interest groups, economic development/business interests, environmental groups, labor, public health, and other advisory groups. The values identified by this task force included:

- Protect the environment

- Protect public/worker health and safety

- "Get on with the cleanup" to achieve substantive progress in a timely manner

- Use a systems design approach that keeps endpoints in mind as intermediate decisions are made

- Establish management practices that ensure accountability, efficiency, and allocation of funds to high-priority items.

DOE convened the HAB in 1994. The HAB is composed of representatives from local and county governments, public interest groups, business interests, the Hanford work force, the Nez Perce Tribe, and the state of Oregon. In addition the HAB will include representatives of DOE, EPA, Ecology, the Confederated Tribes and Bands of the Yakama Indian Nation, and the DOH who will serve in an "ex-officio" capacity. The primary mission of the HAB is to provide informed recommendations and advice to DOE, EPA, and Ecology on selected major policy issues related to the cleanup of the Hanford Site. Through open public meetings the HAB will assist the public in being more informed and involved in Hanford cleanup decisions. 


\section{DOE/RL-89-12, Rev. 2 \\ Draft A}

A major focus of the HAB will be the content of, and the proposed changes to the Tri-Party Agreement, and monitoring agency progress in meeting regulatory milestones. Specific major ground water issues may include:

- The protection of ground water and restoration of contaminated ground water

- Impacts on the Columbia River

- Waste management issues, including the treatment, storage, and/or disposal (TSD) of all solid, hazardous, radioactive, and mixed waste currently at the Site, or generated at the Site in the future. 


\subsection{GROUND WATER PROTECTION STRATEGIES}

The ground water protection strategies at the Hanford Site include source control, monitoring, and remediation. These strategies embody DOE's goals for Site cleanup including DOE's commitment to protecting the Site ground water from further degradation, protecting the Columbia River, and providing a clean and healthy environment open to a variety of uses (DOE/RL 1994b). These strategies follow the ground water protection policies described in Chapter 3 and are implemented by the ground water protection programs described in Chapter 5.

\subsection{SOURCE CONTROL}

Source control actions are designed to prevent degradation of ground water. This is accomplished by pollution prevention, waste minimization, waste isolation or containment, and contaminated soil (vadose zone) remediation.

\subsubsection{Pollution Prevention and Waste Minimization}

The Hanford Site Waste Minimization and Pollution Prevention Awareness Program Plan (DOE/RL 1991) reflects national and DOE waste minimization and pollution prevention goals and policies, and represents an ongoing effort to make pollution prevention and waste minimization part of the Site operating philosophy. Many pollution prevention and waste minimization activities are being implemented that result in the protection of ground water. Most of these activities involve the curtailing of hazardous and radioactive waste discharges to the land which could migrate into the ground water. The highest priority is placed on eliminating all regulated hazardous waste discharges (i.e., pollution prevention). Also of concern is minimizing the amount of discharges with hazardous constituents that are below regulatory levels, yet are above local background levels (i.e., waste minimization).

In accordance with these policies, a hierarchical approach to environmental management has been adopted and is applied to all types of polluting and waste generating activities. Pollution prevention and waste minimization through source reduction are first priority in the Hanford waste minimization/pollution prevention program, followed by environmentally safe recycling. Treatment to reduce the quantity, toxicity, and/or mobility of wastes will be considered only when prevention or recycling are not possible or practical. Environmentally safe disposal is the last option.

Specific waste minimization opportunities are accomplished primarily by the individual waste generating facilities. Waste minimization at these facilities is focused on reducing both the concentration of hazardous compounds in liquid effluents and the total volume of liquid effluents discharged to the soil column which could migrate into the ground water.

Historically, the greatest source of ground water contamination has been the disposal of process wastes and liquid effluents to trenches, cribs, and ponds (i.e., although a great amount of contaminants were adsorbed in the soil column). For example, in 1987 over 23 billion liters ( 6 billion gallons) of liquid effluents were discharged to the soil column. Currently, less than 11 billion liters ( 3 billion gallons) of liquid effluents are being discharged annually, and further reductions are planned (WHC 1994a). To restrict further degradation of the ground water by this 
DOE/RL-89-12, Rev. 2

Draft A

route, DOE and Ecology have signed Consent Order No. DE 91NM-177, also known as the Liquid Effluent Consent Order (Ecology and DOE 1992). Under this order, State Waste Discharge Permits (WAC 173-216 or 216 permit) are required for identified waste streams, and untreated effluent disposal to the soil column will be discontinued after June 1995. The waste streams will be treated with best available technology/all known, available, and reasonable treatment (BAT/AKART) and disposed to a clean soil column. Effluent stream sampling/monitoring, as well as ground water monitoring at the disposal sites will be required with the issuance of the permits. Activities and program objectives for treatment and disposal of liquid effluent streams are described in the Liquid Effluent/Hanford Environmental Compliance FY 1995 Multi-Year Program Plan/Fiscal Year Work Plan WBS 1.2.2.1 and 1.2.2.2 (WHC 1994a).

Source reduction is accomplished through better process design and upgrading of equipment. Numerous waste generating facility upgrades are required by June 1995 to incorporate BAT/AKART, which will ensure discharged wastewater is nonhazardous. One example of BAT/AKART is the implementation of closed loop systems at several facilities. Other facility waste minimization efforts include procedural changes and better housekeeping.

The construction of the 200 Areas Treated Effluent Disposal Facility (TEDF) and the 200 Areas Effluent Treatment Facility (ETF) will provide BAT/AKART treatment and new permitted land discharges of liquid effluents from many Site facilities. However, tritiated water in the treated effluent to be disposed to the soil column from the 200 Areas ETF will result in the introduction of a new tritium contaminant plume to the unconfined aquifer. Tritium cannot be practically removed by current treatment technologies (DOE-RL 1994c).

The 300 Area TEDF will treat wastewater from numerous 300 Area facilities for permitted discharge into the Columbia River instead of into the contaminated process trenches (WHC 1992). Other source control efforts include the construction of permitted and lined evaporation lagoons, such as those in the $100-\mathrm{N}$ Area.

Sanitary wastes on the Hanford Site are generally collected in septic tanks and the effluent is discharged to either a tile field or a disposal area, such as a trench or pond. There are 72 known septic tanks in the 200 Areas and 600 Area of the Site. There is no routine monitoring of the septic systems for tank leakage or tank integrity.

The sanitary waste in the 100 Areas, with the exception of $100-\mathrm{N}$, is discharged to individual septic tanks and associated tile fields. The sanitary waste in the 100-N Area is discharged to the $100-\mathrm{N}$ sewage lagoon through a network of sewer piping and lift stations. There are some septic tanks in 100-N which are pumped and trucked to the 100- $\mathrm{N}$ sewage lagoon. The 100-N sewage lagoon consists of an aeration pond, a stabilization pond, and an infiltration pond (DOE/RL 1994d). Currently, there are 12 septic tanks which are routinely pumped and trucked to the 100-N sewage lagoon for disposal. Sanitary waste in the 200 Areas is predominately discharged to individual septic tanks and associated tile fields. Sanitary waste in the 300 Area is currently discharged to a septic tank via the șanitary sewer and the effluent is discharged to two unlined trenches. The primary 400 Area sanitary sewer system discharges to a septic tank and an unlined sewage lagoon. A second septic tank and tile drainfield system is located in the southwest corner of the 400 Area and services a small number of nearby mobile trailers.

Currently, there are two proposals for eliminating sanitary discharges to the ground in the 300 and 400 Areas. DOE and the city of Richland have negotiated the connection of the 300 Area 
sanitary sewer to the city of Richland sanitary sewer and treatment system. The current schedule is to connect the 300 Area sanitary sewer to the city of Richland sewer system by June 1995 . In the 400 Area, there are two alternatives being evaluated to revise the 400 Area sanitary sewer and eliminate sanitary effluent discharge to the ground. The first alternative is to connect to the WPPSS wastewater treatment facility. Tie-in piping has been installed and RL has been negotiating with WPPSS representatives. At this time, no agreement has been reached for this connection (DOE/RL 1994d). The second, and most likely, alternative is to build a fully lined evaporative lagoon treatment system (DOE/RL 1994d).

\subsubsection{Waste Isolation}

The Barrier Development Program was established in 1986 (Adams and Wing 1986) to design an effective means of isolating wastes from the environment over a considerable period of time (over 1,000 years). The barriers are designed to resist biologic and human intrusion, erosion, and minimize or inhibit the infiltration of moisture. A prototype barrier, representing the culmination of 8 years of barrier research and testing, was recently completed over the 216-B-57 Crib in the 200 East Area. The performance of this system will be monitored over the next three or more years to determine the value of its design for more widespread application.

Precipitation may mobilize and transport hazardous and radioactive contaminants in or on soil through the vadose zone to the ground water. To prevent this ground water contamination mechanism, contaminated soil must either be isolated (contained) or remediated. Proposed soil isolation activities for several contaminated sites include contaminated soil removal (source removal) and subsequent isolation. Removed soil would be disposed in the proposed Environmental Restoration Disposal Facility (ERDF). The ERDF will consist of a large RCRA-compliant, doublelined trench to be filled with low-level and mixed wastes. The filled trench will be capped with an engineered barrier to minimize any percolation through or disturbance of the wastes (DOE/RL 1994e). Some contaminated sites may have barriers built directly over them to isolate and stabilize the wastes in situ (e.g., at the 200-BP-1 operable unit, DOE/RL 1994f).

Surplus buildings contaminated with hazardous and radioactive materials must be decontaminated and decommissioned. Many of these facilities were built in the 1940's as part of the early Site operations, and are located mainly in the 100, 200, and 300 Areas. These facilities include eight plutonium production reactors, several chemical separations/processing plants, laboratory and fuels manufacturing facilities, and ancillary support structures that contain residual radioactive contamination. Decontamination and decommissioning generally may be thought of as a source control strategy for the protection of ground water. The removal of these sources diminishes the potential for long-term ground water contamination. The demolition wastes produced by decommissioning activities may be transported to the Central Plateau for final disposal, possibly under an engineered barrier. Careful consideration will be given to ground water protection when managing wash and rinse waters produced by decontamination activities.

\subsubsection{Soil Remediation}

As described above, a primary soil cleanup method will be removal of waste materials from waste sites and disposal in the ERDF. An alternative to soil removal and soil isolation is contaminated soil remediation. Depending on the nature of the contaminant, threat to worker health 
and safety, location in the soil column, the extent of contamination and other considerations, soil remediation may be the preferred alternative to soil removal and isolation. Remedial options may include:

- In situ vitrification to physically isolate the wastes from the environment

- Bio-remediation to chemically alter contaminants into nonhazardous compounds

- Vapor extraction of volatile and semi-volatile compounds present in contaminated soil

- Chemical fixation of contaminants to isolate the wastes from the environment

- Soil washing.

Since 1990, seven expedited response actions (ERA) (i.e., accelerated cleanup actions at sites to prevent further spread or release of contamination) have been, or are being, conducted at the Hanford Site. These actions include:

- Removal of buried drums containing hexone and uranium from a burial ground in the 300 Area (completed 1991)

- Excavation and consolidation of contaminated soils from the bottom of the 300 Area process trenches (completed 1991)

- Vapor extraction of carbon tetrachloride from the vadose zone of two disposal sites in the 200 West Area (ongoing since 1992)

- Characterization and identification of hazards from the 100 Area Pickling Acid Cribs (completed 1993)

- Excavation and removal of debris from the 100 Area Sodium Dichromate Landfill (completed 1993)

- Excavation and removal of contaminated soils in the northwest corner of the Hanford Site (Riverland) (completed 1993)

- Characterization and remediation of the North Slope disposal sites (completed 1994).

In addition, an accelerated characterization and remediation of abandoned gas wells and sites associated with a NIKE missile launch site and control center on the Fitzner/Eberhardt Arid Lands Ecology Reserve was completed in 1994 and an ERA at the 100 Area N Springs to reduce strontium-90 transport into the Columbia River through ground water is ongoing (Dirkes et al. 1994).

\subsection{MONITORING}

Monitoring of liquid effluents, the vadose zone and ground water are key "near-term" elements in the strategy for protecting Hanford Site ground water. Effluent monitoring is used to determine the character of liquid effluents discharged to the soil column. As previously discussed, liquid effluent discharges to the soil column, which use the soil column as treatment, will be eliminated by June 1995, or will be appropriately permitted (and monitored). Vadose zone and ground water characterization and monitoring of waste source areas (i.e., tank farms, cribs, ponds, burial grounds, and landfills) and contaminant plumes is conducted in accordance with state and 
federal regulations, DOE orders, and the appropriate program plan (see Figure 1). This monitoring is used to determine and document whether contaminants have been released from a waste source area. If contaminants have been released, monitoring is used to assess and document the extent-and rate of contaminant movement in the vadose zone and/or ground water so that the appropriate Ras can be implemented:

\subsection{GROUND WATER REMEDIATION}

The Hanford Sitewide Groundwater Remediation Strategy (DOE/RL 1994a) establishes the overall goals of ground water remediation on the Hanford Site, which are to restore ground water to its beneficial uses in terms of protecting human health and the environment, and allow its use as a natural resource. The Working Group (Drummond 1992) established two categories of ground water use commensurate with various proposed land uses: (1) restricted use or access to ground water in the Central Plateau and in a buffer zone surrounding it, and (2) unrestricted use or access to ground water for all other Site areas.

In recognition of the Working Group and public values, the strategy establishes that the sitewide approach to ground water cleanup is to remediate the major plumes found in the reactor areas (100 Areas) and to contain the spread and reduce the mass of the major plumes found in the Central Plateau (see Figures 5 and 6). Remedial alternatives being considered for the different contaminant plumes are discussed in DOE/RL (1994a).

The ground water remediation strategy is based on a geographic and plume-specific approach. It is intended to reflect tribal and stakeholder values, goals, and priorities. Key elements are:

- Place a high priority on actions that protect the Columbia River and near-shore environment from degradation due to the discharge of contaminated ground water

- Reduce the contamination entering the ground water from existing sources, including the vadose zone

- Control the migration of plumes that threaten or continue to further degrade ground water quality beyond the boundaries of the Central Plateau

- Employ the Hanford Past Practices Strategy (HPPS) (Thompson 1991) to accelerate limited field investigations (LFI), interim remedial measures (IRM), and ERAs (i.e., maintain a bias for action).

The HPPS was implemented for the purpose of streamlining the past-practices corrective action process. This process examines existing information to determine if a given site requires an LFI to gain additional information. If the existing information indicates that a given site poses an immediate threat to human health and the environment, an ERA will be undertaken. An IRM may be performed prior to the final RA, providing that sufficient information exists on which to base the IRM. 
DOE/RL-89-12, Rev. 2

Draft A

Ground water remediation will be performed under the CERCLA program (see Section 5.2). In general, a site identified for cleanup will go through remedial investigation (RI) and feasibility study (FS). The RI emphasizes data collection and site characterization. The FS is used to analyze data gathered under the RI, and develop options for an RA. Final ground water cleanup requirements are issued by the EPA and recorded in the Record of Decision. Additional strategy details are discussed in the Hanford Sitewide Groundwater Remediation Strategy (DOE/RL 1994a). 


\subsection{GROUND WATER PROTECTION PROGRAMS}

For the past 50 years, many activities have been performed to characterize and monitor the ground water at the Hanford Site. In more recent years, protection of the ground water has become a high priority. In this section, current Site ground water programs and activities are summarized. The current ground water programs and activities are dedicated to the monitoring, protection, and subsequent remediation of the Site ground water resource. The current programs fulfill the policy requirements set forth by applicable federal and state regulations and DOE orders summarized in Chapter 3, as well as the policy requirements set forth in the Tri-Party Agreement (Ecology et al. 1989).

Although the various programs each have a different overall objective, they all have a common, fundamental need to understand the Site hydrogeologic system and the dynamic processes involved. The acquisition of basic hydrogeologic and related information, as well as contaminant monitoring, is essential for an understanding of the system, so that informed decisions can be made regarding ground water protection and management. Ground water protection management activities and interrelationships which cross program boundaries are depicted in Figure 7. Thus, regardless of whether CERCLA, RCRA, state-implemented programs, or other ground water programs are being addressed, the same general information base is needed, as well as a common process for obtaining that information.

\subsection{RCRA GROUND WATER ACTIVITIES}

The RCRA ground water monitoring program at Hanford implements the ground water protection provisions of 40 CFR 264 Subpart F and 40 CFR 265 for 20 individual projects on the Site. The RCRA program involves application for permits to operate regulated TSD units, detection and compliance monitoring of the vadose zone and ground water to detect and assess possible contamination from the TSD units, and corrective measures including development of TSD closure plans and cleanup actions. Ground water monitoring at a TSD facility is designed to distinguish upgradient ground water conditions from conditions downgradient of the TSD so that any TSD impacts to ground water can be assessed. The RCRA ground water monitoring program at Hanford also complies with Washington State Dangerous Waste Regulations (WAC 173-303-400) and Minimum Functional Standards for Solid Waste Handling (WAC 173-304-490).

Ground water monitoring plans developed for each regulated unit have been approved by Ecology. These plans, and subsequent revisions, include specifications for well locations and construction, hydrogeologic characterization, sampling parameters, analysis, and reporting. The focus of these plans is on detection and assessment monitoring of the aquifer at the waste management boundary (point of compliance). The intent of these requirements is to determine if ground water contamination has occurred from these facilities and what, if any, corrective actions may be necessary. Analytical data from ground water monitoring at RCRA facilities are presented in quarterly and annual reports (e.g., WHC 1994b, 1994c). 
DOE/RL-89-12, Rev. 2

Draft A

Figure 7. Ground Water Management Activities and Inter-relationships.

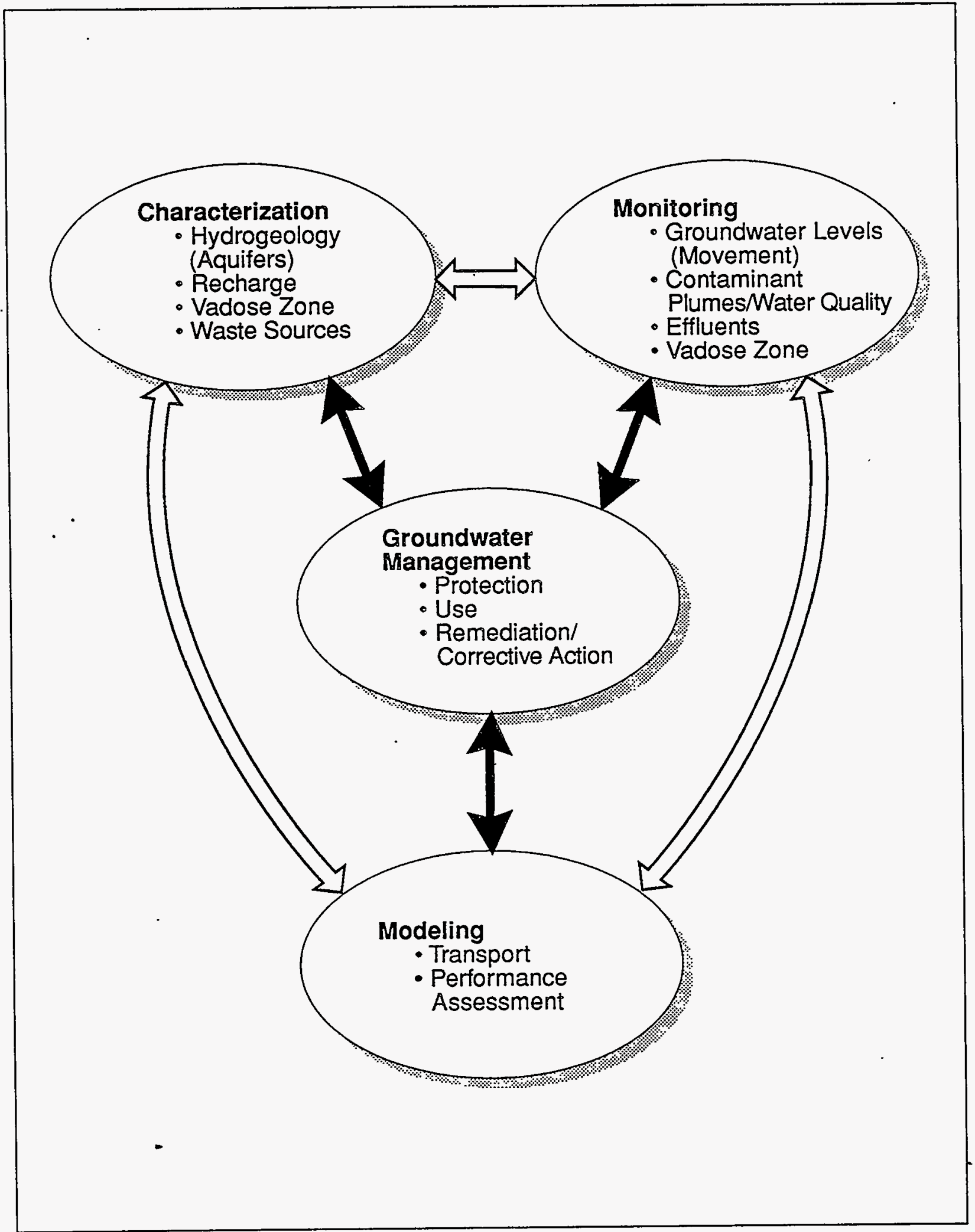

$943-1107 / 50167 / 10-21-94$ 
Ground water monitoring networks for several additional facilities have been prioritized and scheduled in the overall program for meeting RCRA permitting needs at Hanford. This program plan has been incorporated into the Tri-Party Agreement Action Plan schedule. RCRA compliance monitoring and performance assessment monitoring will continue through the final closure or postclosure period (typically 30 years) for all RCRA TSD units at Hanford.

\subsection{CERCLA GROUND WATER ACTIVITIES}

The Hanford Site has been divided into 78 operable units, or groupings of similar waste units within a geographic area, so that the CERCLA process established in the National Oil and Hazardous Substances Contingency Plan (40 CFR 300) can be efficiently implemented. Ground water monitoring and related site characterization for operable units are treated separately to allow for differences between the more localized contaminants in the soil column at the sources and the more widespread distribution of ground water contaminant plumes that have resulted from one or more individual sources. The concept of the ground water operable unit was adopted to allow separate characterization of the source operable units and the ground water. There are 10 ground water operable units at the Hanford Site. Monitoring wells are located and sampled in accordance with RI/FS work plans so as to define the nature and extent of the contaminant plume(s), as opposed to the point of compliance well networks required under RCRA at individual TSD units. Ground water operable units are described in Appendix D of the Tri-Party Agreement.

The CERCLA process and the HPPS were briefly outlined in Section 4.3. Ground water monitoring requirements at individual waste units and operable units are implemented by site-specific RI/FS or LFI work plans. The monitoring data are presented in RI or LFI reports that are used to develop FS or IRM reports so that the appropriate remedial alternative can be identified. The results of the characterization and monitoring activities are used in ground water flow and transport models to provide input to risk assessment and FS evaluations. The modeling activities also provide input to the monitoring and characterization programs, as depicted in Figure 7. The Hanford Sitewide Groundwater Remediation Strategy (DOE/RL 1994a) outlined in Section 4.3 will be implemented through the CERCLA program.

CERCLA ground water activities at the various operable units have been prioritized in accordance with the Tri-Party Agreement milestone schedule (Ecology et al. 1989), which sets a milestone date for all inactive waste sites to be cleaned up by the year 2018 .

\subsection{OPERATIONAL GROUND WATER ACTIVITIES}

Operational monitoring at Hanford dates from the early days of Site operations. The original objective of the program was to evaluate the effect of disposal operations on ground water quality with the specific objective of determining when it was necessary to replace a soil column disposal facility. Early emphasis was placed on radionuclide monitoring, although nitrate was tracked from a relatively early date, due to its widespread use at the site and high mobility in ground water. The current purposes of the Operational Ground Water Program are (1) to document compliance with state and federal ground water quality standards and monitoring requirements for facilities not yet covered by state permit, RCRA, or CERCLA monitoring, (2) to provide an early warning of unusual occurrences and trends that may be associated with those facilities, and (3) to coordinate ground water activities conducted by the Site maintenance and operations contractor. The Operational Ground 
DOE/RL-89-12, Rev. 2

Draft A

Water Program implements the "near-field" or facility monitoring requirements of DOE Orders 5820.2A, 5400.1, and 5400.5, as well as monitoring requirements specified in Consent Order No. DE 91NM-177 (Ecology and DOE 1992).

Sites monitored by the Operational Ground Water Program include the $100-\mathrm{K}$ basins, 200 East and West Area cribs, ditches and ponds, and 400 Area ponds that are controlled under DOE orders and by Tri-Party Agreement milestones (Johnson 1993). The latter consist primarily of soil column disposal facilities for chemical and radioactive liquid wastes that were associated with nuclear materials processing, refining, and waste treatment activities.

As previously discussed, discharge of liquid effluents to the soil column will be eliminated, or permitted, by June 1995 (Ecology and DOE 1992). During the interim, detailed evaluation of the impact of certain non-RCRA-regulated facilities on ground water quality was required (Tri-Party Agreement Milestone M-17-13). In addition, an agreement was reached in December 1991 to include all miscellaneous waste streams and/or any new waste stream discharged to the ground under the State Waste Discharge Permit Program (WAC 173-216). The 216 permit sites described in Section 5.7 will require ground water monitoring and will be part of the Operational Ground Water Program.

The Operational Ground Water Program summarizes geological, geochemical, and hydrological information gathered each year in the Westinghouse Hanford Company Operational Groundwater Status Report (e.g., Johnson 1993).

\subsection{SITEWIDE GROUND WATER SURVEILLANCE}

The GWSP provides an integrated, sitewide assessment of ground water quality on the Hanford Site and an assessment of potential offsite impacts by DOE operations. The GWSP helps meet objectives stated in DOE Order 5400.1 (DOE 1988a) for an environmental surveillance program, but its focus is on the "far-field" evaluation as opposed to the "near-field" evaluations of the RCRA and Operational Ground Water Programs.

The GWSP is designed to satisfy the following objectives:

- Identify and quantify existing, emerging, or potential ground water quality problems

- Review ground water quality data gathered on the Hanford Site and prepare an assessment of the condition.of the ground water

- Assess the potential for contaminants to migrate offsite through the ground water pathway.

More than 800 wells are used by the GWSP, RCRA, CERCLA, and Operational Ground Water Programs to monitor both the unconfined and the upper-confined aquifers. Monitoring well locations, sampling frequency, and constituents are identified each year in the Environmental Surveillance Master Sampling Schedule (Bisping 1994). Sampling and analysis for the GWSP is coordinated with ground water monitoring conducted by the RCRA, CERCLA, and Operational programs to eliminate unnecessary redundancy and is reflected in Bisping (1994). Wells are selected to monitor ground water in six general categories: contaminant source areas, known contaminant 
plumes, near water supplies, Hanford Site perimeter, off the Hanford Site, and background or reference areas. The GWSP also reviews ground water monitoring programs, plans, and results conducted to meet other Hanford Site monitoring needs (e.g., RCRA monitoring and CERCLA work plans), and identifies additional data collection and analysis needed to meet environmental surveillance requirements.

Sampling and analysis results from all programs are evaluated on an ongoing basis to describe the areal extent and temporal trends of contamination. Results and conclusions are reported and summarized in the Hanford Site Environmental Report (e.g., Dirkes et al. 1994), and reported in detail in annual ground water monitoring reports (e.g., Dresel et al. 1994).

\subsection{VADOSE ZONE ACTIVITIES}

Vadose zone monitoring is recognized as an important early warning system in protecting the Site ground water from any further degradation, and is noted as an activity requiring increased sitewide emphasis and coordination (see Chapter 7). The interplay between stratigraphy and disposal operations is an important element to be determined by vadose zone characterization and monitoring. Vadose zone activities are currently conducted at the single-shell tanks (SST) in the 200 Areas (tank farms); at inactive cribs, trenches, ditches, and ponds (waste management); and as part of various CERCLA operable unit characterization investigations and ERAs (environmental restoration) as summarized in the following sections.

\subsubsection{Tank Farms}

A total of 149 SSTs and 28 double-shell tanks (DST) were constructed beginning in 1943 to contain radioactive wastes resulting from the processing of irradiated uranium fuels for plutonium recovery (Anderson 1990). These wastes have been stored as alkaline slurries in the underground tanks. Due to the nature of these wastes, much effort is spent in maintaining and monitoring the tanks and their contents. The tanks are located in 15 tank farms in the 200 East and 200 West Areas.

The DSTs are designed to contain and detect wastes that may leak through the primary tank shell. Any leak that occurs would be contained and detected within the secondary shell. This design makes additional leak detection (e.g., vadose zone or ground water monitoring) unnecessary.

Sixty-seven of the SSTs are assumed to be leaking. Of this number, eight tanks have not been interim stabilized. An estimated total of 2.3 to 3.4 million liters $(600,000$ to 900,000 gallons) may have leaked into the soil column from the 67 tanks (Welty 1988; Hanlon 1994). Leak detection for the SSTs is accomplished by the monitoring of liquid and sludge levels in those tanks containing nonboiling wastes. Additionally, as of May 1994, 760 vadose zone monitoring wells (dry wells) adjacent to the 149 SSTs are monitored at weekly to yearly frequencies using borehole geophysical logging instruments to obtain gamma and neutron radiation profiles of the vadose zone around each SST. An elevated radiation reading indicates a breach of tank integrity, and a leak or mobilization of an existing leak. 
Each SST is surrounded by 2 to 12 vadose zone monitoring wells that are 6 inches in diameter, open at the bottom, and extend approximately 75 feet below the surface. Tank farms such as 240-A and 241-SX, and others, are each equipped with a buried horizontal vadose monitoring system. These systems consist of horizontal borings beneath each tank, which allow for instrument access for radiation and temperature profiles to assess tank integrity.

Current plans call for the installation of liquid level devices in all of the SSTs. This will provide a more direct and reliable means of leak detection than the current vadose zone monitoring method. Three new borehole geophysical logging trucks equipped with high-resolution, spectral gamma-ray probes will provide increased capability and capacity to monitor the tank farm vadose zone monitoring wells starting in late 1994. This monitoring will provide data on the characterization, extent, and mobility of wastes that have leaked into the vadose zone. Installation of additional vadose zone monitoring wells may be needed to characterize the contaminant plumes. Currently, monitoring is for radioactive wastes, but the capability may be expanded to include monitoring for hydrogen and limited chemical monitoring (under development).

RCRA ground water monitoring wells have also been installed around the tank farms to assist in the leak monitoring operation. These wells are used by the RCRA program to determine any impacts on the ground water regime in accordance with 40 CFR 264 and 40 CFR 265.

\subsubsection{Waste Management}

Over 1,000 vadose zone monitoring wells are located adjacent to ponds, cribs, and ditches that were used for the disposal of liquid effluents from past site operations. Borehole geophysical logging, similar to that conducted for the tank farm dry wells, is conducted in selected wells on a (typically) multiyear frequency. The wells that are logged and the logging frequency are based on the pattern of contamination and any radionuclide movement determined from the historical radiological profiles for these wells. Vadose zone monitoring is also conducted daily at the unlined Solid Waste Landfill using a basin lysimeter that was installed beneath the active trench to collect and monitor liquid effluents (leachate). The monitoring results, which have not detected any leachate yet, will be documented in the annual operations report (e.g., ICF Kaiser 1993).

\subsubsection{Environmental Restoration}

Vadose zone investigations at CERCLA operable units have typically included collection and analysis of vadose zone soil samples for physical properties and chemistry (e.g., DOE/RL 1990a, $1994 \mathrm{~g}$ ) or soil gas investigations of vadose zone waste units (e.g., DOE/RL 1990b, 1993c) to characterize the nature and extent of contaminants in the vadose zone. The 200 West Area carbon tetrachloride ERA required significant vadose zone characterization so that the vapor extraction systems, which are currently operating, could be properly designed (Last and Rohay 1993). 


\subsection{UNDERGROUND STORAGE TANKS}

In October 1991, Ecology finalized the "Underground Storage Tank Regulations" (WAC 173-360), which control the underground storage of petroleum products and "other regulated substances." However, radioactive materials (Subject to Subtitle C of the federal Solid Waste Disposal Act of 1974) and mixed wastes are exempt from these regulations. Sections $345(6)(\mathrm{g})$ and 520 of WAC 173-360 set provisions for ground water monitoring in conjunction with underground storage tanks (UST). Recent agreements between DOE and Ecology have acknowledged this state code as the underlying authority for vadose zone and ground water monitoring and other applicable activities concerning USTs.

To bring the Hanford Site USTs into compliance with WAC 173-360, Project L-044 "Hanford Infrastructure Underground Storage Tanks" was designed to replace, eliminate, or upgrade 33 existing USTs, which range in age from 2 to 45 years (WHC 1989). Initial work on Project L-044 started in April 1994 and is currently ongoing. The project is approximately one-third complete and is expected to be finished in January 1995.

Leak detection for existing USTs is done by manually gauging the tanks either weekly, monthly, or through daily inventory control, depending on the size and purpose of the tank. The tanks, along with their associated pressurized piping, are tightness-tested every 3 years, or annually for USTs used for emergency purposes. In accordance with WAC 173-360, new USTs are either constructed of fiberglass-reinforced plastic or are installed with a cathodic leak-protection system.

Another UST program, operated since 1988, involves the identification and removal of inactive USTs on the Hanford Site. These inactive USTs were associated with facilities that have been shut down. This program completed removal of the 56 identified inactive USTs in mid-1994.

\subsection{LIQUID EFFLUENT AND STATE WASTE DISCHARGE (210) PERMITS}

In December 1991, Ecology and DOE signed Consent Order No. DE 91NM-177, also known as the Liquid Effluent Consent Order (Ecology and DOE 1992). Under this order, permits administered by WAC 173-216, "State Waste Discharge Permit Program," (SWDP or 216 Permit) or the National Pollutant Discharge Elimination System (NPDES) (see Section 5.9.2), are required for waste streams identified in the Consent Order. The Consent Order identifies Phase I and II streams. Approximately 400 miscellaneous streams have been subsequently identified. The streams have been categorized by compositional and flow rate characteristics. This order is distinct from, though consistent with, the Tri-Party Agreement.

RL is constructing the 200 Areas ETF to provide effluent treatment and disposal capability for the Central Plateau by June 1995. The initial mission of the 200 Areas ETF (Project C-018H) is to provide treatment of process condensate from the 242-A Evaporator. Treated effluent from the 200 Areas ETF will be disposed to a crib-type discharge facility called the State-Approved Land Disposal Site, which is being constructed north of the 200 West Area. A second liquid effluent project, the 200 Areas TEDF (Project W-049H), will provide a network of piping in both the 200 East and 200 West Areas. The 200 Areas TEDF will discharge the treated effluent to a new pondtype State-Approved Land Disposal Site located east of the 200 East Area. 
Disposal of treated effluent from these facilities to the ground will likely result in some localized changes in ground water flow directions. Of greater significance to ground water remediation is the presence of potentially high concentrations (maximum $6,000,000$ picocuries per liter) of tritiated water in the treated effluent to be disposed to the soil column from the 200 Areas ETF. Tritium cannot be practically removed by treatment (DOE/RL 1994c). This will result in the introduction of a new tritium contaminant plume to the unconfined aquifer. The 200 Areas ETF has been approved by Ecology after going through the State Environmental Policy Act process and a 216 Permit application has been submitted to the state.

Related to the 216 permit project are monitoring requirements attendant to Tri-Party Agreement Milestone M-17-00, "Complete liquid effluent treatment facilities/upgrades for all Phase I streams." Under this milestone, disposal to the soil column for all untreated effluent will cease as of June 1995. Treated effluent disposal basins receiving treated effluents will incorporate ground water monitoring required by the 216 Permit project as part of their operation, which will be conducted by the Operational Ground Water Program.

A 216 permit requires submittal of an engineering report evaluating BAT/AKART for the waste stream (WAC 173-240-130). The engineering report must include a geohydrologic evaluation of the liquid effluent receiving site. Also, sampling and analysis plans are required for liquid effluents, and ground water impact assessments are required for some specific disposal sites. The sampling program for this activity is conducted by the Operational Ground Water Program.

Currently, all required 216 permit applications have been submitted on schedule, meeting all the milestones established in the Liquid Effluent Consent Order and the Tri-Party Agreement. It is anticipated that ground discharge of all untreated Phase I effluent streams will cease by the milestone date of June 1995. These permit applications are either going through, or will soon go through a public comment period, and thereafter a draft permit will likely be issued. Subsequent negotiations between DOE and Ecology will determine the final requirements of the permits (i.e., sampling parameters, sampling frequency, reporting requirements). Ongoing negotiations between DOE and Ecology will determine the overall regulatory strategy for the disposition of liquid effluent discharges identified in the inventory of miscellaneous streams.

\subsection{ONSITE PROJECT COORDINATION}

Onsite coordination of the Hanford Site ground water wells is provided through the Well Administrator Team, and coordinated management of the ground water data from these programs is provided through the centralized Hanford Environmental Information System (HEIS) and other databases.

\subsubsection{Well Administrator Team}

The Well Administrator Team is a multiorganizational element with a central role in monitoring well oversight at Hanford. Regular participants in meetings and the Well Administrator Team efforts include representatives of RL and their prime contractors. This group has proven to be effective in its role of monitoring well oversight, having identified a "custodian" for each Site welI 
and prioritized wells for decommissioning. Well issues have been successfully resolved between the well custodians, typically without involvement of the entire team. Team meetings are called if there is a need, typically on a monthly basis.

\subsubsection{Hanford Environmental Information System}

HEIS is a consolidated set of automated resources that are intended to manage the data gathered during ground water and environmental monitoring and restoration of the Hanford Site. The HEIS includes an integrated database that provides consistent and current data to all users and promotes sharing of data by the entire user community.

Data stored in HEIS are collected under several regulatory programs. Included are data and vadose zone and ground water analytical results from the CERCLA, RCRA, Operational and GWSP, as well as soil data, hydrogeological data and tank characterization data. Verification and validation qualifiers for analytical results are also stored in HEIS.

As the title suggests, HEIS is an information system with an inclusive database. Although the database is the nucleus of the system, HEIS also provides user access software: menu-driven data entry, reporting, extraction, and browsing facilities; an ad hoc query facility; and two-dimensional graphics. However, as a general purpose database, HEIS cannot, by itself, meet all of the specific data needs of its various users. Additional tools are required to perform work more efficiently.

\subsubsection{Auxiliary Data Tools}

Complementing HEIS are a number of user-tailored systems that permit more efficient access and manipulation of specific data sets. All of these systems are coordinated with HEIS to ensure consistent information content but are separate from HEIS to allow certain flexibilities.

The Liquid Effluent Monitoring Information System (LEMIS) is an online database and information system designed to track and record sampling and analysis events for all Phase I and Phase II liquid effluent streams (WHC 1993). LEMIS also allows linkage of related sampling events and analysis for reporting purposes.

The Geosciences Data Analysis Toolkit (GeoDAT) computer system provides data management features and analytical applications for manipulating ground water data, which are not currently available in HEIS. GeoDAT was primarily created to serve the specific needs of RCRA users, but it does include data from all Hanford ground water monitoring programs. With GeoDAT, users can analyze and report their data using a more familiar software environment than that currently found in HEIS.

Cartographic and spacial analysis needs are met through the Hanford Geographic Information System (HGIS). This application integrates tabular data found in HEIS with a spacial database of features at the Hanford Site, such as waste facility locations, geologic configuration, and contaminant extent. Data often require the spacial representation afforded by HGIS for effective interpretation and display. 


\section{DOE/RL-89-12, Rev. 2}

Draft A

Current information on the details of monitoring well construction, water levels, well ownership, and locations/elevations are provided in the ASBUILT and WELLDOX applications. These systems, while containing mostly data found in HEIS, offer alternative methods of displaying and manipulating this information particularly for personnel involved in well maintenance.

\subsection{OTHER ACTIVITIES}

\subsubsection{U.S. Ecology}

U.S. Ecology operates a commercial, low-level landfill on land leased from the state of Washington within the boundaries of the Hanford Site (see Figure 2). The site occupies 100 acres, located south of the 200 East Area. The DOH has the authority to implement applicable U.S. Nuclear Regulatory Commission requirements for the landfill.

Currently, U.S. Ecology monitors local ground water quality at five monitoring wells. One well is located upgradient, outside of the U.S. Ecology site, and is used to determine upgradient ground water quality. Three wells are located downgradient, near the burial trenches, to monitor for any impact the trenches may have on the ground water. Another well is located further downgradient, off the U.S. Ecology site. As the landfill is expanded and trenches are added, additional monitoring wells will be installed. A total of 23 wells are expected to be eventually installed.

The ground water monitoring wells are sampled monthly for a comprehensive list of radiological and hazardous constituents of concern. The DOH takes split samples at the time of sampling. All ground water sample reports are supplied to DOE for informational purposes.

In addition to ground water monitoring, soil gas monitoring of the vadose zone is conducted beneath the trenches in three vadose zone monitoring wells. Two wells are located near the landfill trenches, and one is located away from the trenches, and serves as a background monitoring point. These existing vadose zone wells are conventional vertical borings. Three additional vadose zone monitoring wells are planned. The new wells will be angled borings to allow vapor sampling from directly beneath the trenches.

Soil gas from the vadose zone monitoring wells is sampled quarterly and analyzed for radon, tritium, and organic constituents. The results of these analyses are published in an annual environmental report (e.g., U.S. Ecology 1994).

\subsubsection{National Pollutant Discharge Elimination System}

Although not directly related to the ground water protection program, the NPDES program requires permits and monitoring activities for effluent/waste streams discharged to surface water bodies, in this case, the Columbia River. The water quality of the Columbia River affects the nearriver unconfined aquifer during high-water stage, when the river recharges the aquifer (see Section 2.4). 
In 1981, the Hanford Site was issued an NPDES permit authorizing the discharge of seven waste streams. Today, only three of the seven streams are active. These streams are routinely monitored for various parameters, which may include $\mathrm{pH}$, temperature, flow volume, free available chlorine, total suspended solids, oil and grease, iron, ammonia, and chromium. Sampling activities for each outfall are summarized and reported to the EPA each month (e.g., Woodruff et al. 1991). The application for a new NPDES permit for discharge of the treated effluent from the 300 Area TEDF has been submitted to the regulatory agencies. 
DOE/RL-89-12, Rev. 2

Draft A

This page intentionally left blank. 


\subsection{GROUND WATER ISSUES}

\subsection{REGULATORY INTERFACE}

Several federal and state regulations are applicable to activities affecting ground water. Because these regulations are applied to facilities, contaminant areas, and activities often situated in the same location, there are overlapping regulatory programs with potentially conflicting requirements and conditions to be satisfied. Some of the issues raised by this overlap of regulatory programs are described below:

- Disposal of liquid effluents to the ground or surface waters that are generated by certain CERCLA pump and treat actions may be subject to WAC 173-216 requirements. For example, partially treated ground water that must be returned to the ground may. exceed state ground water quality criteria, and thereby may be in conflict with state requirements. Additional treatment for co-contaminants is identified as a major factor in determining the scope and feasibility of many of the ground water cleanup projects on the Hanford Site

- RCRA "derived-from" and "mixture" rules for listed waste, as administered by Ecology under WAC 173-303, could result in additional regulatory requirements for CERCLA cleanup actions (although these have been resolved for well purge water and laboratory wastes). This would delay the start of remediation efforts if substantive requirements of RCRA are imposed

- Movement of ground water and reintroduction of treated ground water for CERCLA remediations will result in changes to ground water flow paths, water table elevation, and plume trajectories. This could compromise the effectiveness and potential regulatory compliance of portions of the RCRA ground water monitoring network.

Effective and expedient implementation of ground water remediation depends on clarification and resolution of these and other potentially conflicting regulatory issues. Therefore, it is essential for there to be close and open contact between DOE and its contractors, EPA, and Ecology.

\subsection{PROGRAM INTERFACE}

Numerous programmatic ground water issues arise due to the proximity of RCRA TSDs and CERCLA operable units, the complexity of ground water remediation and other ground water issues, and the administration of the various ground water programs and functions by the different Site contractors. These issues require implementation of the GPMP by RL so that program goals and Tri-Party Agreement milestones are achieved in a cost-effective manner and ground water program responsibilities are clearly assigned. DOE has provided direction in the past as to the ground water program responsibilities between the Waste Management (EM-30) and Environmental Restoration (EM-40) programs.

Programmatic issues such as wellhead protection of ground water resource wells, vadose zone characterization and monitoring, and ground water monitoring coordination affect several programs, contractors, and RL divisions. For example, ground water remediation will affect portions of the 
existing monitoring well networks and could reduce the ability to properly monitor the RCRA TSD units. These effects must be identified and resolved. Refinement of the existing monitoring networks and better coordination with the ground water remediation monitoring effort is needed to better define the extent of plumes, their movement, and the progress of ground water contamination cleanup.

Sitewide ground water modeling capabilities are currently maintained by at least two of the Hanford Site contractors. These capabilities support the specific ground water protection activities that have been assigned to each contractor by RL, and as each program has specific objectives and needs for analytical capabilities, $R L$ needs to evaluate the programmatic interface (see Section 7.4).

Continued and improved interaction and communication among programs, contractors, the regulators, the tribes, stakeholders, and DOE will be necessary as ground water remediation and monitoring proceeds. In recognition of this need, DOE is implementing a plan that will provide a forum for ground water issue resolution and informed decision making so that the program goals and objectives are efficiently coordinated. This implementation plan is discussed in Chapter 7 .

\subsection{AUDIT FINDINGS AND STATUS}

The need for improved coordination to manage ground water protection on the Hanford Site has been cited, both implicitly and specifically, in successive audit findings from 1986 through 1994. This section presents a brief chronological synopsis of these findings.

The 1986 audit findings highlighted specific problems and potential problems of ground water contamination on the Hanford Site (DOE 1987; DOE/RL 1988). These were addressed in the Hanford Environmental Management Program (DOE/RL 1986; WHC 1990), the Hanford Environmental Management Program Implementation Plan (WHC 1988), and a subsequent RL Action Plan.

In May and June 1990, the Hanford Site Tiger Team Assessment was conducted as part of a 10-point initiative by DOE to strengthen environmental protection and waste management (DOE 1990b). Among the findings of this audit were:

- "Inadequate Characterization of the Hydrogeologic regime"

- "Deficiencies in Geophysical Surveys of Monitoring Wells"

- "Inadequate Well Abandonment."

The GPMP, then only recently written (DOE/RL 1989), was cited in these findings and corresponding responses as a mechanism for resolving these issues. However, these findings represent work items not completed, primarily because of funding limitations rather than coordination issues. 
In May 1992, the Hanford Site Environment, Safety, and Health Progress Assessment Team evaluated the effectiveness of actions taken in response to Tiger Team findings (DOE 1992). Two concerns of this audit were:

- "The Hanford Site Groundwater Protection Management Program Plan (October 1989) has not been implemented as written per the requirements set forth in DOE 5400.1"

- "RL does not have a formal Groundwater Protection Management Program to coordinate and integrate all Hanford Site programs that protect, characterize, or monitor ground water."

The first item was addressed by including a limited implementation plan in Revision 1 of the GPMP (DOE/RL 1993b). The second item is addressed by the present version of the GPMP (this document).

The most recent audit concerning the GPMP was conducted in May 1994 (DOE 1994). Pertinent findings of this audit were:

- "The multiple ground water monitoring programs at Hanford are not fully integrated into a sitewide monitoring program"

- "Elements of the Hanford GPMP have not been fully implemented."

Responses to the 1994 findings were prepared to address GPMP deficiencies from all previous audits. Proposed actions accompanying the responses include:

- This revision of the GPMP will include a better definition of the purpose, rationale, and long-term strategy for the various ground water monitoring programs (e.g., RCRA, CERCLA) and activities at Hanford

- RL has established the Hanford Hydrogeologic Coordination Group to serve as the focal point for sitewide coordination of hydrogeologic (i.e., ground water and vadose zone) investigations and studies conducted in support of the RL mission.

A Hydrogeologic Coordination Group Chair will head the group

- The GPMP. will provide guidance and direction for coordination of ground water activities and programs. The GPMP will address existing and anticipated ground water uses, resource needs, and water-resource management policies

- The GPMP will address and coordinate the Hanford Sitewide Groundwater Remediation Strategy (DOE/RL 1994a).

RL has appointed a single point of contact, the Hydrogeologic Coordination Group Chair, to lead the Hanford Ground Water Management Team. This team, its purposes, and initial duties are discussed in Chapter 7. 
DOE/RL-89-12, Rev. 2

Draft A

This page is intentionally left blank 
DOE/RL-89-12, Rev. 2

Draft A

\subsection{IMPLEMENTATION PLAN}

In accordance with the proposed actions developed in response to the May 1994 audit findings, RL has prepared this implementation plan to fully implement the GPMP and to improve coordination of the Hanford Site ground water programs and activities. This plan provides a framework for establishing the Hanford Hydrogeologic Coordination Group, which will incorporate the Hanford Ground Water Management Team and the Ground Water Protection Group and outlines the roles and responsibilities of each program participant. The Hanford Hydrogeologic Coordination Group mission is to provide hydrogeologic management expertise necessary to implement planning, coordination, and operational support for all RL programs that require hydrologic/hydrogeologic information. These groups and their functions are described in the following sections. The Hanford Hydrogeologic Coordination Group participants are shown in Figure 8. The coordination group is managed by the Hanford Ground Water Management Team, which is composed of RL representatives of each of the RL programs involved in activities that affect ground water resources. The Ground Water Protection Group is composed of both technical and management representatives from the various site programs and functions from the Hanford Site contractors as shown in Figure 8.

\subsection{BACKGROUND}

Currently there are several informal mechanisms in place to facilitate efficient, cost-effective management within and among the various ground water protection programs. This has resulted in improved interprogram communication, reduction of redundant effort, and interprogram standardization. For example, to standardize the analytical quality assurance/quality control protocols and meet the requirements of all of the programs, DOE developed the Hanford Analytical Services Quality Plan (DOE/RL 1994h).

Audits summarized in Section 6.3 found that the multiple ground water monitoring programs at Hanford are not fully coordinated and that several elements of the GPMP have not been fully implemented. Although coordination of the various ground water monitoring programs has been attempted in the past through a number of informal working groups, this approach has not fully coordinated these programs, eliminated all redundant activities, or resulted in the free exchange of information at Hanford. Establishment of the formal Hanford Hydrogeologic Coordination Group, the Hanford Ground Water Management Team, and the Ground Water Protection Group by RL will provide a more effective organizational vehicie for improved coordination and implementation of the GPMP mission.

\subsection{HANFORD GROUND WATER MANAGEMENT TEAM}

The Hanford Ground Water Management Team (see Figure 8) is composed of $R L$ representatives of each of the RL programs involved in activities that may affect ground water. These team members work together with the Hydrogeologic Coordination Group Chair to implement the GPMP. The Team will meet regularly to address ground water coordination issues. Additional RL staff and Ground Water Protection Group representatives will attend these meetings when their input is required. The following sections describe the responsibilities and functions of the Hanford Ground Water Management Team. 




943-1107/50157/10-21-94 


\subsubsection{Hydrogeologic Coordination Group Chair}

The Hydrogeologic Coordination Group Chair serves as the focal point for communication between the Hanford Ground Water Management Team and the Ground Water Protection Group, and will be the meeting moderator for both groups. The Chair will solicit both groups for issues and meeting agenda items for consideration.

\subsubsection{Hanford Ground Water Management Team Members}

The Hanford Ground Water Management Team is comprised of representatives of each of the RL programs involved in activities that may affect ground water: Waste Management; Environmental Restoration; Operations and Transition; Tank Waste Storage; Environmental Assurance, Policy, and Permits; Planning and Integration; Technology Development; and Environmental Surveillance. The responsibilities and authorities of each team member include:

- Provide leadership to the Team regarding their respective program activities and plans that may affect ground water. Serves as focal point for representing respective program's coordination and implementation issues before the Team

- Perform day-to-day functions necessary to accomplish the Hydrogeologic Program mission

- Fully participate in Team meetings, implement all decisions of the Team that affect their respective program areas, and ensure that contractor organizations, through the respective program management chain, abide by the decisions of the Team.

\subsection{GROUND WATER PROTECTION GROUP}

The Ground Water Protection Group is composed of both technical and management representatives from the various site programs/functions shown in Figure 8. These representatives will meet regularly to address ground water coordination issues. The responsibilities of the individual representatives will include:

- Function as "point of contact" for the representative's site program/function for all activities and plans that may affect ground water. Serve as focal point for representing respective program/function's coordination and implementation issues before the Hanford Ground Water Management Team

- Fully participate in meetings with Management Team program representative, Hanford Ground Water Management Team, or with other programs/functions so that all activities and plans that may affect ground water can be efficiently implemented and coordinated 
DOE/RL-89-12, Rev. 2

Draft A

- Inform fellow program/function staff of all decisions of the Team that affect their respective program areas, communicate ground water and other technical information from program/function to HEIS and others to facilitate informed decision making by other representatives and Team members, consider the effects of their program function activities on other programs/functions, serve as a clearing house for ground water-related information and issues, and engage in problem resolution related to ground water issues.

\subsection{HANFORD HYDROGEOLOGIC COORDINATION GROUP VISION}

The Hanford Hydrogeologic Coordination Group will coordinate vadose zone and ground water activities on the Hanford Site. This includes strategic guidance for ground water protection, remediation, performance assessment, effluent controls and treatment of liquid discharges to the soil column, ground water withdrawal and treatment, and the coordination of characterization and monitoring activities. The intent of the coordination group is to prevent duplication of activities, ensure that information is freely exchanged and more efficiently disseminated to all participants involved in vadose zone and ground water activities, and serve as the central focal point for implementation of the GPMP.

The success of the Hanford Hydrogeologic Coordination Group will primarily depend on regular interaction of group participants, the effectiveness of information exchange, and effective, timely reporting. Issues of ground water management and protection will be discussed and deliberated by both the Hanford Ground Water Management Team and the Ground Water Protection Group and taken into advisement by the Hydrogeologic Coordination Group Chair. These issues and the positions taken on the issues will be presented to RL senior management by the Chair for decision or resolution.

The success of the coordination group also depends on providing all affected programs functions with relevant data in a timely fashion. This data exchange will be made possible through the use of the HEIS database. Tasks such as ground water and soil sampling, analysis, and reporting will not be considered complete until the resultant data are into the HEIS database and maps or graphics are loaded into the HGIS. HEIS will be the centralized point of reporting, sharing, and coordination of hydrologic, vadose zone, and ground water data for the Hanford Site.

\subsection{GOALS AND SCHEDULE}

Implementation of the GPMP is already underway, with the establishment of the Hanford Ground Water Management Team and the appointment of the Hydrogeologic Coordination Group Chair by RL in May 1994. Numerous ground water management issues have been identified that 
require resolution and are identified as "first orders of business" for the Hanford Hydrogeologic Coordination Group. Some of these items have been cited in recent audits (see Section 6.3). Initial actions include:

- Define charter duties, establish program/function representatives, leadership, and meeting schedule for the Ground Water Protection Group, and prioritize actions

- Determine methods for increased interaction with the tribes and stakeholders with regard to ground water issues

- Propose means of resolution for outstanding DOE audit findings that focus on ground water protection and management (see Section 6.3)

- Determine organization of, responsibilities for, and funding sources for an annual Ground Water Status Report (see Section 7.6)

- Review all vadose zone monitoring and characterization activities on the Hanford Site, and identify unanswered programmatic and sitewide needs (and regulatory requirements) for increasing vadose zone monitoring/characterization

- Review pertinent ground water regulatory issues and conflicts and propose actions for resolution

- Determine impacts of remedial activities on other ground water programs and propose coordination measures.

Subsequent actions, such as review of the Memorandum of Understanding for implementation of the Hanford Environmental Management Program and Environmental Restoration and Waste Management Five-Year Plan to assess their impacts on the ground water programs are planned to be completed by the end of calendar year 1994. Efforts such as reviewing water level measurements by both the Operational and Sitewide programs are planned to be done by June 1995, and review of the Operational program for compliance with DOE orders is planned to be done by September 1995 . A recommendation of whether modeling efforts by the various Site contractors are needed by RL is planned to be made by September 1995 .

Implementation of the GPMP is also governed by the priority for waste site cleanup, the action plan established in the Tri-Party Agreement (Ecology et al. 1989), and the requirement to eliminate disposal of untreated effluents to the soil column after June 1995 in accordance with the Liquid Effluent Consent Order (Ecology and DOE 1992). Significant progress has been made in meeting the milestone schedules of these agreements (Figure 9), which is contributing to the achievement of the overall goals and objectives of the GPMP.

\subsection{INFORMATION EXCHANGE}

The success of the Hanford Hydrogeologic Coordination Group depends on providing all affected programs/functions with relevant data in a timely fashion. This information exchange will be made possible through the use of centralized databases, regular meetings and, possibly, preparation of an annual Ground Water Status Report on Hanford Site ground water activities. Tasks such as 




H9409005.2 
hydrogeologic sampling, analysis, and reporting will not be considered complete until the resultant data are entered into the HEIS database and maps or graphics are loaded into the HGIS. HEIS will be the centralized point of sharing and coordination of hydrologic, vadose zone, and ground water data for the Hanford Site.

Depending upon funding availability, a Ground Water Status Report could be prepared on an annual basis with input from all Ground Water Protection Group representatives. This report could provide a comprehensive status of all ground water-related activities on site. This publicly available document could include a geographically keyed summary of all ground water-related activities conducted at CERCLA operable units, RCRA TSD facilities, Solid Waste Discharge Permit facilities, and support facilities across the site. Pertinent information that could be presented in the report for each program/function might include:

- Geographic area

- Description of each program/project

- Description and status of activities affecting the vadose zone or ground water

- Status of relevant Tri-Party Agreement milestones

- Stage of program/project in the regulatory process

- Summary and disposition of ground water-related issues that affect the program/project coordination and implementation.

- Recommendations for actions to address issues

- Implementing organization(s) and representative point of contact.

The report could include an annual bibliography and keyword compilation for all published reports relevant to ground water issues at Hanford. This bibliography could include information on:

- Water table maps

- RCRA quarterly and annual reports

- CERCLA work plans, reports, and studies

- Operational monitoring report

- Sitewide monitoring report

- Special studies

- Research reports

- Technology development reports for ground water remediation. 


\section{DOE/RL-89-12, Rev. 2}

Draft A

The report could also include references for data sources, databases, and data custodians. This might include items such as:

- Volume and quality of effluents discharged to the soil column (from LEMIS database)

- Hydrochemical characterization data (from GeoDAT analytical tool)

- Updates on HEIS categories and information

- Updates on HGIS categories and information. 
DOE/RL-89-12, Rev, 2

Draft A

\subsection{REFERENCES}

10 CFR 61, "Licensing Requirements for Land Disposal of Radioactive Waste," Code of Federal Regulations, as amended.

10 CFR 834, "Proposed Radiation Protection of the Public and the Environment, Notice of Proposed Rule," 58 FR 16268, Federal Register, March 25, 1993.

40 CFR 61, "National Emission Standards for Hazardous Air Pollutants," Code of Federal Regulations, as amended.

40 CFR 122, "EPA Administered Permit Programs: The National Pollutant Discharge Elimination System," Code of Federal Regulations, as amended.

40 CFR 123, "State Program Requirements," Code of Federal Regulations, as amended.

40 CFR 124, "Procedures for Decision Making," Code of Federal Regulations, as amended.

40 CFR 125, "Criteria and Standards for the National Pollutant Discharge Elimination System," Code of Federal Regulations, as amended.

40 CFR 129, "Toxic Pollutant Effluent Standards," Code of Federal Regulations, as amended.

40 CFR 130, "Water Quality Planning and Management," Code of Federal Regulations, as amended.

40 CFR 131, "Water Quality Standards," Code of Federal Regulations, as amended.

40 CFR 136, "EPA Regulations on Test Procedures for the Analysis of Pollutants," Code of Federal Regulations, as amended.

40 CFR 141, "EPA National Primary Drinking Water Regulations," Code of Federal Regulations, as amended.

40 CFR 143, "EPA National Secondary Drinking Water Regulations," Code of Federal Regulations, as amenided.

40 CFR 144, "Underground Injection Control Program," Code of Federal Regulations, as amended.

40 CFR 145, "State UIC Program Requirements," Code of Federal Regulations, as amended.

40 CFR 146, "Underground Injection Control Program: Criteria and Standards," Code of Federal Regulations, as amendẹ.

40 CFR 147, "State Underground Injection Control Programs," Code of Federal Regulations, as amended.

40 CFR 148, "Hazardous Waste Injection Restrictions," Code of Federal Regulations, as amended. 
DOE/RL-89-12, Rev. 2

Draft A

40 CFR 149, "Sole Source Aquifers," Code of Federal Regulations, as amended.

40 CFR 162, "State Registration of Pesticide Products," Code of Federal Regulations, as amended.

40 CFR 163, "Certification of Usefulness of Pesticide Chemicals," Code of Federal Regulations, as amended.

40 CFR 164, "Rules of Practice Governing Hearings, under the Federal Insecticide, Fungicide, and Rodenticide Act, Arising from Refusals to Register, Cancellations of Registrations, Changes of Classifications, Suspensions of Registrations and Other Hearings Called Pursuant to Section 6 of the Act," Code of Federal Regulations, as amended.

40 CFR 165, "Regulations for the Acceptance of Certain Pesticides and Recommended Procedures for the Disposal and Storage of Pesticides and Pesticide Containers," Code of Federal Regulations, as amended.

40 CFR 191, "Environmental Radiation Protection Standards for Management and Disposal of Spent Nuclear Fuel, High-Level and Transuranic Radioactive Wastes," Code of Federal Regulations, as amended.

40 CFR 192, "Health and Environmental Protection. Standards for Uranium and Thorium Mill Tailings," Code of Federal Regulations, as amended.

40 CFR 196, "EPA Radiation Site Cleanup Regulation, Advanced Notice of Proposed Rule," 58 FR 54474, Federal Register, October 21, 1993.

40 CFR 257, "Criteria for Classification of Solid Waste Disposal Facilities and Practices," Code of Federal Regulations, as amended.

40 CFR 260, "Hazardous Waste Management System-General," Code of Federal Regulations, as amended.

40 CFR 264, "Standards for Owners and Operators of Hazardous Waste Treatment, Storage and Disposal Facilities," Code of Federal Regulations, as amended.

40 CFR 265, "Interim Status Standards for Owners and Operators of Hazardous Waste Treatment, Storage, and Disposal Facilities," Code of Federal Regulations, as amended.

40 CFR 267, "Interim Standards for Owners and Operators of New Hazardous Waste Land Disposal Facilities," Code of Federal Regulations, as amended.

40 CFR 300, "National Oil and Hazardous Substances Contingency Plan," Code of Federal Regulations, as amended.

40 CFR 761, "Polychlorinated Biphenyls (PCBs) Manufacturing, Processing, Distribution in Commerce, and Use Prohibitions," Code of Federal Regulations, as amended.

Adams, M. R., and N. R. Wing, 1986, Protective Barrier and Warning Marker System Development Plan, RHO-RE-PL-35P, Rockwell Hanford Operations, Richland, Washington. 
Anderson, J. D., 1990, A History of the 200 Area Tank Farms, WHC-MR-0132, Westinghouse Hanford Company, Richland, Washington.

Atomic Energy Act of 1954, 42 USC 2011 et seq.

Bierschenk, W. H., 1959, Aquifer Characteristics and Ground-Water Movement at Hanford, HW-60601, General Electric Company, Hanford Atomic Products Operation, Richland, Washington.

Bisping, L. E., 1994,-Environmental Surveillance Master Sampling Schedule, PNL-9215, Pacific Northwest Laboratory, Richland, Washington.

Clean Water Act of 1977, 33 USC 1251 et seq.

Comprehensive Environmental Response, Compensation, and Liability Act of 1980, 42 USC 9601 et seq.

Delaney, C. D., K. A. Lindsey, and S. P. Reidel, 1991, Geology and Hydrology of the Hanford Site: A Standardized Text for Use in Westinghouse Hanford Company Documents and Reports, WHC-SD-ER-TI-003, Westinghouse Hanford Company, Richland, Washington.

Dirkes, R. L., 1990, 1988 Hanford Riverbank Springs Characterization Report, PNL-7500, Pacific Northwest Laboratory, Richland, Washington.

Dirkes, R. L., R. W. Hanf, and R. K. Woodruff, editors, 1994, Hanford Site Environmental Report for Calendar Year 1993, PNL-9823, Pacific Northwest Laboratory, Richland, Washington.

DOE, 1984, Radioactive Waste Management - Guidance Document, DOE Order 5820.2A, U.S. Department of Energy, Washington, D.C.

DOE, 1987, Environmental Survey Preliminary Report, Hanford Site, Richland, Washington, DOE/EH/OEV-05-P, U.S. Department of Energy, Washington, D.C.

DOE, 1988a, General Environmental Protection Program, DOE Order 5400.1, U.S. Department of Energy, Washington D.C.

DOE, 1988b, Site Characterization Plan, Reference Repository Location, Hanford Site, Washington; Consultation Draft, DOE/RW-0164, U.S. Department of Energy, Office of Civilian Radioactive Waste Management, Washington, D.C.

DOE, 1989, Comprehensive Environmental Response, Compensation, and Liability Act Program, DOE Order 5400.4, U.S. Department of Energy, Washington, D.C.

DOE, 1990a, Radiation Protection of the Public and the Environment, DOE Order 5400.5, U.S. Department of Energy, Washington D.C.

DOE, 1990b, Tiger Team Assessment of the Hanford Site, DOE/EH-0139, U.S. Department of Energy, Washington, D.C. 
DOE/RL-89-12, Rev. 2

Draft A

DOE, 1992, Environment, Safety and Health Progress Assessment of the Hanford Site, DOE/EH-0271, U.S. Department of Energy, Washington, D.C.

DOE, 1994, Draft Routine Environmental Audit of the Hanford Site, Richland, Washington,

U.S. Department of Energy, Office of Environmental Audit, Washington, D.C.

DOE/RL, 1986, Hanford Environmental Management Program Plan, HEMP-1, U.S. Department of Energy, Richland Field Office, Richland, Washington.

DOE/RL, 1988, DOE-RL Action Plan Responding to Findings in the DOE-HQ Environmental Survey Preliminary Report, Hanford Site, U.S. Department of Energy, Richland Field Office, Richland, Washington.

DOE/RL, 1989, Hanford Site Groundwater Protection Management Program, DOE/RL-89-12, Rev. 0, U.S. Department of Energy, Richland Field Office, Richland, Washington.

DOE/RL, 1990a, Remedial Investigation/Feasibility Study Work Plan for the 300-FF-5 Operable Unit, Hanford Site, Richland, Washington, DOE/RL-89-14, U.S. Department of Energy, Richland Field Office, Richland, Washington.

DOE/RL, 1990b, Phase 1 Remedial Investigation Report for the Hanford Site 1100-EM-1 Operable Unit, DOE/RL-90-18, Vols. 1 and 2, U.S. Department of Energy, Richland Field Office, Richland, Washington.

DOE/RL, 1991, Hanford Site Waste Minimization and Pollution Awareness Program Plan, DOE/RL-91-31, Rev. 1, U.S. Department of Energy, Richland Operations Office, Richland, Washington.

DOE/RL, 1993a, Hanford Site Development Plan, DOE/RL-93-19, U.S. Department of Energy, Richland Operations Office, Richland, Washington.

DOE/RL, 1993b, Hanford Site Groundwater Protection Management Program, DOE/RL-89-12, Rev. 1, U.S. Department of Energy, Richland Field Office, Richland, Washington.

DOE/RL, 1993c, Phase 1 Remedial Investigation Report for the 300-FF-1 Operable Unit, DOE/RL-92-43, Rev. 0, U.S. Department of Energy, Richland Operations Office, Richland, Washington.

DOE/RL, 1994a, Hanford Sitewide Groundwater Remediation Strategy, DOE/RL-94-95, Draft A, U.S. Department of Energy, Richland Operations Office, Richland, Washington.

DOE/RL, 1994b, Hanford Site Strategic Plan, RL-D94-048, U.S. Department of Energy, Richland Operations Office, Richland, Washington.

DOE/RL, 1994c, Tritiated Waste Water Treatment and Disposal Evaluation 1994, DOE/RL-94-77, U.S. Department of Energy, Richland Operations Office, Richland, Washington.

DOE/RL, 1994d, State Waste Discharge Permit Application 100-N Sewage Lagoon, DOE/RL-94-22, Rev. 0, U.S. Department of Energy, Richland Operations Office, Richland, Washington. 
DOE/RL, 1994e, Remedial Investigation and Feasibility Study for the ERDF, DOE/RL-93-99, Rev. 1, U.S. Department of Energy, Richland Operations Office, Richland, Washington.

DOE/RL, 1994f, Feasibility Study Report for the 200-BP-1 Operable Unit, DOE/RL-93-35, Rev. 1, U.S. Department of Energy, Richland Operations Office, Richland, Washington.

DOE/RL, 1994g, Remedial Investigation/Feasibility Study Work Plan for the 200-UP-1 Groundwater Operable Unit, Hanford Site, Richland, Washington, DOE/RL-92-76, U.S. Department of Energy, Richland Operations Office, Richland, Washington.

DOE/RL, 1994h, Hanford Analytical Services Quality Plan, DOE/RL-94-95, U.S. Department of Energy, Richland Operations Office, Richland, Washington.

Dresel, P. E., S. P. Lutrell, J. C. Evans, W. D. Webber, P. D. Thorne, M. A. Chamness, B. M. Gillespie, B. E. Opitz, J. T. Rieger, and J. K. Merz, 1994, Hanford Site Ground-Water Monitoring for 1993, PNL-10082, Pacific Northwest Laboratory, Richland, Washington.

Drummond, M. E., 1992, The Future for Hanford: Uses and Cleanup, The Final Report of the Hanford Future Site Uses Working Group.

Early, T. O., S. H. Hall, and V. G. Johnson, 1988, "Tritium, Carbon-14 and Iodine-129 as - Indicators for Localized Vertical Recharge Along an Anticline in the Columbia River Basalts Using a Decay-Corrected Mixing Model," in Proceedings of the Ground Water Geochemistry Conference, National Water Well Association, Dublin, Ohio.

Ecology and DOE, 1992, "In the matter of the compliance by United States Department of Energy with Chapter 70.105 and 90.48 RCW and the Rules and Regulations of the Department of Ecology," Consent Order DE 91NM-177 (for the permitting of liquid effluent discharges under Washington Administrative Code 173-216), dated February 3, 1992, Washington State Department of Ecology, Olympia, Washington.

Ecology, EPA, and DOE, 1989, Hanford Federal Facility Agreement and Consent Order, 2 vols., Washington State Department of Ecology, U.S. Environmental Protection Agency, and the U.S. Department of Energy, Washington, D.C.

Endangered Species Act of 1973, 16 USC 1531 et seq.

Federal Insecticide, Fungicide, and Rodenticide Act of 1975, 7 USC 136 et seq.

Foster, R. F., and R. H. Wilson, 1965, Evaluation of Radiological Conditions in the Vicinity of Hanford for 1964, BNWL-90, Battelle Northwest Laboratory, Richland, Washington.

Freshley, M. D., and M.J. Graham, 1988, Estimation of Ground-Water Travel Times at the Hanford Site: Description, Past Work and Future Needs, PNL-6328, Pacific Northwest Laboratory, Richland, Washington. 
Friedrichs, D. R., C. R. Cole, and R. C. Arnett, 1977, Hanford Pathline Calculational Program Theory, Error Analysis and Applications, ARH-ST-149, Atlantic Richfield Hanford Company, Richland, Washington.

Gee, G. W., 1987, Recharge at the Hanford Site: Status Report, PNL-6403, Pacific Northwest Laboratory, Richland, Washington

Gee, G. W., M. J. Fayer, M. L. Rockhold, and M. D. Campbell, 1992, "Variations in Recharge at the Hanford Site," Northwest Science, Vol. 66, pp. 237-250.

Gerber, M. S., 1992, Legend and Legacy: Fifty Years of Defense Production at the Hanford Site, WHC-MR-0293, Rev. 2, Westinghouse Hanford Company, Richland, Washington.

Graham, M. J., G. V. Last, and K. R. Fecht, 1984, An Assessment of Aquifer Intercommunication in the B Pond-Gable Mountain Pond Area of the Hanford Site, RHO-RE-ST-12P, Rockwell Hanford Operations, Energy Systems Group, Richland, Washington.

Hanford Tank Waste Task Force, 1993, Final Report Hanford Tank Waste Task Force.

Hanlon, B. M., 1994, Tank Farm Surveillance and Waste Status for May 1994, WHC-EP-0182-74, Westinghouse Hanford Company, Richland, Washington.

ICF Kaiser Hanford Company, 1993, Annual Report for Solid Waste Landfill Operations, Calendar Year 1993, OSS-D-94-400, ICF Kaiser Hanford Company, Richland, Washington.

Jenkins, O. P., 1922, "Underground Water Supply of the Region About White Bluffs and Hanford," Bulletin No. 26, Division of Geology, State of Washington Dept. of Conservation and Development, Olympia, Washington, $41 \mathrm{pp}$.

Johnson, V. G., 1993, Westinghouse Hanford Company Operational Groundwater Status Report, 1990-1992, WHC-EP-0595, Westinghouse Hanford Company, Richland, Washington.

Johnson, V. G., D. L. Graham, and S. P. Riedel, 1993, Methane in Columbia River Basalt Aquifers: Isotopic and Geohydrologic Evidence for a Deep Coal-Bed Source in the Columbia Basin, Washington, American Association of Petroleum Geologists Bulletin, v. 77, no. 7, pp. 1192-1297.

Kipp, K. L., and R. D. Mudd, 1973, Collection and Analysis of Pump Test Data for Transmissivity Values, BNWL-1709, Pacific Northwest Laboratory, Richland, Washington.

Last, G. V., B. N. Bjornstand, M. P. Bergeron, D. W. Wallace, D. R. Newcomer, J. A. Schramke, M. A. Chamness, C. S. Cline, S. P. Airhart, and J. S. Wilbur, 1989, Hydrogeology of the 200 Areas Low-Level Burial Grounds - An Interim Report, PNL-6820, Pacific Northwest Laboratory, Richland, Washington. 
Last, G. V., and V. J. Rohay, 1993, Refined Conceptual Model for the Volatile Organic Compounds-Arid Integrated Demonstration and 200 West Area Carbon Tetrachloride Expedited Response Action, PNL-8597, Pacific Northwest Laboratory, Richland, Washington.

Liikala, T. L., 1994, Hydrogeology Along the Southern Boundary of the Hanford Site Between the Yakima and Columbia Rivers, Washington, PNL-10094, Pacific Northwest Laboratory, Richland, Washington.

Lindsey, K. A., 1991, Revised Stratigraphy for the Ringold Formation, Hanford Site, South-Central Washington, WHC-SD-EN-EE-004, Westinghouse Hanford Company, Richland, Washington.

Lindsey, K. A., M. A. Connelly, and B. N. Bjornstad, 1991, Geologic Setting of the 200 West Area: An Update, WHC-SD-EN-TI-008, Westinghouse Hanford Company, Richlạn, Washington.

Lindsey, K. A., B. N. Bjornstad, J. W. Lindberg, and K. M. Hoffmann, 1992, Geologic Setting of the 200 East Area: An Update, WHC-SD-EN-TI-012, Westinghouse Hanford Company, Richland, Washington.

Mullineaux, D. R., R. E. Wilcox, W. F. Ebaugh, R. Fryxell, and M. Rubin, 1978, "Age of the Last Major Scabland Flood of the Columbia Plateau in Eastern Washington," Quaternary Research, v. 10, p. 171-180.

Newcomb, R. C., J. R. Strand, and F. J. Frank, 1972, Geology and Ground-water Characteristics of the Hanford Reservation of the U.S. Atomic Energy Commission, Washington, U.S. Geological Survey Professional Paper 717, U.S. Geological Survey, Washington, D.C.

Parker, G. G., and A. M. Piper, 1949, Geologic and Hydrologic Features of the Richland Area, Washington, Relevant to Disposal of Waste at the Hanford Operations Office of the Atomic Energy Commission, USGS-WP-7, U.S. Government Printing Office, Washington, D.C.

Peterson, R. E., and V. G. Johnson, 1992, Riverbank Seepage of Groundwater Along the Hanford Reach of the Columbia River, Washington, WHC-EP-0609, Westinghouse Hanford Company, Richland, Washington.

Piper, A. M., 1944, "Adequacy of Public Water Supplies in the Hanford Barracks and Richland Village Areas of the Hanford Engineer Works (Project 9536) Hanford, Washington, USGS typewritten memorandum, U.S. Government Printing Office, Washington, D.C.

PNL, 1994, Monitoring Ground-Water and River Interaction Along the Hanford Reach of the Columbia River, PNL-9437, Pacific Northwest Laboratory, Richland, Washington.

RCW 36.70A, "Growth Management Act," Revised Code of Washington.

RCW 90.44, "Regulation of Public Ground Water," Revised Code of Washington.

RCW 90.48, "Water Pollution Control Act," Revised Code of Washington.

RCW 90.54, "Washington State Water Resources Act," Revised Code of Washington. 
DOE/RL-89-12, Rev. 2

Draft A

Resource Conservation and Recovery Act of 1976, 42 USC 6901 et seq.

Rockhold, M. L., M. J. Fayer, G. W. Gee, and M. J. Kanyid, 1990, Natural Ground water Recharge and Water Balance at the Hanford Site, PNL-7215, Pacific Northwest Laboratory, Richland, Washington

Routson, R. C., and V. G. Johnson, 1990, "Recharge Estimates for the Hanford Site 200 Areas Plateau", Northwest Science, Vol. 64, pp. 150-158.

Safe Drinking Water Act of 1974,42 USC 300 f et seq.

Superfund Amendments and Reauthorization Act of 1986, 42 USC 6921 et seq.

Thompson, K. M., 1991, Hanford Past Practices Strategy, DOE/RL-91-40, Rev. 0, U.S. Department of Energy, Richland Operations Office, Richland, Washington.

Thorne, P. D., M. A. Chamness, F. A. Spane, Jr., V. R. Vermeul, and W. D. Webber, 1993, Three-Dimensional Conceptual Model for the Hanford Site Unconfined Aquifer System, FY 1993 Status Report, PNL-8971, Pacific Northwest Laboratory, Richland, Washington.

Toxic Substances Control Act of 1976, 15 USC 2601 et seq.

Uranium Mill Tailings Radiation Control Act of 1978, 42 USC 2014 et seq.

U.S. Ecology, 1994, Annual Environmental Monitoring Report for Calendar Year 1993, U.S. Ecology Richland, Washington Low-Level Radioactive Waste Disposal Facility, U.S Ecology, Richland, Washington.

WAC 173-100, "Ground water Management Areas and Programs," Washington Administrative Code, as amended.

WAC 173-150, "Protection of Withdrawal Facilities Associated with Ground Water Rights," Washington Administrative Code, as. amended.

WAC 173-154, "Protection of Upper Aquifer Zones,". Washington Administrative Code, as amended.

WAC 173-160, "Minimum Standards for Construction and Maintenance of Wells," Washington Administrative Code, as amended.

WAC 173-200, "Water Quality Standards for Ground Waters of the State of Washington," Washington Administrative Code, as amended.

WAC 173-201a, "Water Quality Standards for Surface Waters of the State of Washington," Washington Administrative Code, as amended.

WAC 173-216, "State Waste Discharge Permit Program," Washington Administrative Code, as amended.

WAC 173-218, "Underground Injection Control Plan," Washington Administrative Code, as amended. 
DOE/RL-89-12, Rev. 2

Draft A

WAC 173-240, "Submission of Plans and Reports for Construction of Wastewater Facilities," Washington Administrative Code, as amended.

WAC 173-303, "Dangerous Waste Regulations," Washington Administrative Code, as amended.

WAC 173-303-645, "Release from Solid Waste Management Units," Washington Administrative Code, as amended.

WAC 173-304, "Minimal Functional Standards for Solid Waste Handling," Washington Administrative Code, as amended.

WAC 173-340, "Model Toxics Control Act-Cleanup," Washington Administrative Code, as amended.

WAC 173-360, "Underground Storage Tank Regulations," Washington Administrative Code, as amended.

WAC 173-563, "Instream Resources Protection Program for the Main Stem Columbia River in Washington State," Washington Administrative Code, as amended.

WAC 173-564, "Water Resources Protection Program for the Main Stem of the Snake River in Washington State," Washington Administrative Code, as amended.

WAC 246-272, "On-Site Sewage Disposal," Washington Administrative Code, as amended.

WAC 246-290, "Department of Public Health Standards for Drinking Water Supplies, Washington Administrative Code, as amended.

WAC 365-190, "Minimum Guidelines to Classify Agricultural, Forest, Mineral Lands, and Critical Areas," Washington Administrative Code, as amended.

Welty, R. K., 1988, Waste Tank Storage Status and Leak Detection Criteria, WHC-SD-WM-TI-356, Rev. 0, Vol. 1, Westinghouse Hanford Company, Richland, Washington.

WHC, 1988, Hanford Environmental Management Program Implementation Plan, WHC-EP-0180, Westinghouse Hanford Company, Richland, Washington.

WHC, 1989, Conceptual Design Report Hanford Infrastructure Underground Storage Tanks, WHC-SD-L044-CDR-001, Rev. 0, Westinghouse Hanford Company, Richland, Washington.

WHC, 1990, Hanford Environmental Management Program Plan, WHC-SP-0518, Rev. 1, Westinghouse Hanford Company, Richland, Washington.

WHC, 1992, Engineering Summary Report Hanford 300 Area Treated Effluent Disposal Facility Project L-045H, WHC-SD-L045H-ER-002, Rev. 0, Westinghouse Hanford Company, Richland, Washington.

WHC, 1993, Liquid Effluent Monitoring Information System (LEMIS) Users Guide, WHC-SD-WM-UM-015, Rev. 0, Westinghouse Hanford Company, Richland, Washington. 
DOE/RL-89-12, Rev. 2

Draft A

WHC, 1994a, Liquid Effluent/Hanford Environmental Compliance FY 1995 Multi-Year Program Plan/Fiscal Year Work Plan WBS 1.2.2.1 and 1.2.2.2, WHC-SP-1097, Westinghouse Hanford Company, Richland, Washington.

WHC, 1994b, Quarterly Report of RCRA Groundwater Monitoring Data for Period January 1, 1994 through March 31, 1994, DOE/RL-94-36-1, U.S. Department of Energy, Richland Operations Office, Richland, Washington.

WHC, 1994c, Annual Report for RCRA Groundwater Monitoring Projects at Hanford Site Facilities for 1993, DOE/RL-93-88, Rev. 0, Westinghouse Hanford Company, Richland, Washington.

Woodruff, R. K., R. W. Hanf, M. G. Hefty, and R. E. Lundgren (editors), 1991, Hanford Site Environmental Report for Calendar Year 1990, PNL-7930, Pacific Northwest Laboratory, Richland, Washington. 
DOE/RL-89-12, Rev. 2, Draft A

\section{DISTRIBUTION}

Number of copies

\section{OFFSITE}

2

1

U.S. Department of Energy, Headquarters

M. K. Harmon

EM-442

Confederated Tribes of the

Umatilla Indian Reservation

P.0. Box 638

Pendleton, Oregon 97801

J. R. Hilkinson

T. Gilmore

Nez Perce Indian Tribe

P.0. Box 365

Lapwai, Idaho 83540-0365

D. Powaukee

Oregon Department of Energy

625 Marion St. N.E.

Salem, OR 97310

M. Blazek

Oregon Department of Hater Resources

555 13.th Street, NE

Salem, Oregon 97310

R. Patt

3

U.S. Environmental Protection Agency

712 Swift BouTevard, Suite 5

Richland, Washington 99352

D. Sherwood

D: Falk (2)

1

Hanapum Indian Band

P.0. Box 878

Ephrata, WA 98823

R. Buck, Jr. 


$$
\begin{aligned}
& \text { DOE/RL-89-12, Rev. 2, } \\
& \text { Draft A } \\
& \text { DISTRIBUTION (cont.) }
\end{aligned}
$$

\section{Number of copies}

\section{OFFSITE}

3

2

2

ONSITE

34

U.S. Department of Energy, Richland Operations office

D. C. Bryson

C. E. Clark

J. K. Erickson

R. D. Freeberg

M. J. Furman (10)

J. B. Hall

J. M. Hennig

R. D. Hildebrand (10)

R. G. Holt, Acting Manager

L. S. Mamiya

R. 0. Puthoff

R. S. 011ero

C. 0 . Ruud

R. P. Saget

K. M. Thompson

RL Public Reading Room

S7-55

A5-15

A5-19

A5-19

R3-81

A5-55

S7-55

A5-55

A5-15

K8-50

A5-10

R3-81

S7-54

A5-54

A5-19

A1-65

Bechtel Hanford, Inc.

R. L. Collins

H4-80

K. R. Fecht

S. C. Foelber

H4-80

H4-80

A. J. Knepp

J. F. Nemec

S. R. Weil

H4-80

H4-80

H4-80 


$$
\begin{aligned}
& \text { DOE/RL-89-12, Rev. 2, } \\
& \text { Draft A } \\
& \text { DISTRIBUTION (cont.) }
\end{aligned}
$$

\section{Number of copies}

\section{ONSITE}

MAC Technical Services Company (MACTEC)

S. D. Barry

$57-73$

Pacific Northwest Laboratory

R. H. Bryce

$K 6-96$

S. P. Luttrel1

K6-96

Technical Files

P8-55

U.S. Army Corps of Engineers

M. P. Johansen (10)

A5-19

150

Hestinghouse Hanford Company

D. B. Barnett (131)

H6-06

J. H. Cammann

H6-06

J. H. Fassett

M. G. Gardner

H6-06

D. G. Horton

N3-06

V. G. Johnson

A. G. Law

J. S. Schmid

J. C. Sonnichsen

R. R. Thompson

T. B. Veneziano

B. A. Williams

H6-06

H6-06

H6-06

H6-06

H6-06

H6-32

H6- 10

J. D. Hilliams

H6-06

M. T. York

Central Files

OSTI (2)

EPIC

H6-28

H6-32

L8-04

L8-07

Information Release Administration

WHC Geosciences Library

H4-51

H4-17

H6-06 
DOE/RL-89-12, Rev. 2,

Draft $A$

This page intentionally left blank.

Distr-Q 